Discussion Paper No. 05-84

There's no Place Like Home

A Strategic Framework to

Overcome Liability of Foreignness

in the German Car Market

Wolfgang Sofka and Jörg Zimmermann

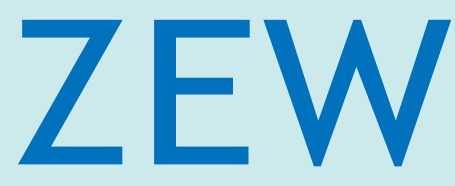

Zentrum für Europäische Wirtschaftsforschung $\mathrm{GmbH}$

Centre for European

Economic Research 
Discussion Paper No. 05-84

\title{
There's no Place Like Home
}

\author{
A Strategic Framework to \\ Overcome Liability of Foreignness \\ in the German Car Market
}

Wolfgang Sofka and Jörg Zimmermann

Download this ZEW Discussion Paper from our ftp server:

ftp://ftp.zew.de/pub/zew-docs/dp/dp0584.pdf

Die Discussion Papers dienen einer möglichst schnellen Verbreitung von neueren Forschungsarbeiten des ZEW. Die Beiträge liegen in alleiniger Verantwortung der Autoren und stellen nicht notwendigerweise die Meinung des ZEW dar.

Discussion Papers are intended to make results of ZEW research promptly available to other economists in order to encourage discussion and suggestions for revisions. The authors are solely responsible for the contents which do not necessarily represent the opinion of the ZEW. 


\section{Non-technical summary}

Technological breakthroughs (most notably the internet) and ideological changes especially in China and India translate into enormous business opportunities from globalization. To turn these potentials into profits companies need the necessary capabilities in place to compete successfully on foreign markets; or, in other words, to overcome their liabilities of foreignness when they venture outside of their home market and face competitors that are highly adapted to their domestic competitive environment. A lack of cultural and social embeddedness leads to frictional losses that manifest themselves in frequent mistakes, unnecessary risks and delayed decision making. While several studies have identified the challenges from liabilities of foreignness, practitioners found it difficult to derive countervailing strategies. This study is designed to address this issue and extend the existing research in two ways. Firstly, we suggest a management tool based on market data that allows managers to estimate their firm's individual degree of liability of foreignness. Secondly, we establish a strategic framework that puts these estimates in perspective and shows ways for effective strategy optimization. We apply our concept to a tangible industry case study: the German automotive market.

We identify two major results: Foreign automotive competitors are not discriminated in Germany in general and a clever management can overcome liabilities of foreignness. We highlight strategic challenges and opportunities where these leveraging effects could be achieved most effectively and efficiently. We find these strategic leverage points in disruptive changes of a society (such as caused by Germany's reunification) that invalidate the established social network and open up chances for newcomers from abroad to develop local embeddedness at equal rates as domestic competitors. On the German automotive market such opportunities arise primarily in East Germany while the socio-cultural effects of liabilities of foreignness appear more deeply rooted in the Western part. Besides, we identify a broader rational for all car producers to engage early and decisively in untapped, promising foreign markets (such as China) to prevent liabilities of foreignness and learn at equal rates as domestic competitors. 


\title{
There's no Place Like Home
}

\section{A strategic framework to overcome liability of foreignness in the German car market.}

\author{
Wolfgang Sofka ${ }^{1}$ and Jörg Zimmermann ${ }^{2}$
}

\begin{abstract}
Globalization has led to exciting new business opportunities around the globe. Still, national and cultural boundaries have not evaporated into a "borderless world." Several studies have identified so-called liabilities of foreignness that arise from a lack of embeddedness and roots in the host market and subsequent competitive disadvantages. Countervailing strategies for these effects have remained scarce so far. We suggest that this is due to the lack of a viable approach to identify and quantify these effects and develop a conceptual framework to empirically estimate the individual degree of liability of foreignness of a firm from a market perspective. We suggest that disruptive changes in a society change the dynamics of liability of foreignness and generate opportunities for foreign companies to optimize their localization strategies. We apply our approach to a large mature market with established international competition: the German new car market. For a comprehensive sample of roughly 1,400 car models from 2003 we estimate the relative turnover disadvantage for all major foreign manufacturers. We find that most foreign producers have managed to overcome liabilities of foreignness in Germany through firm-specific advantages. Still, some face significant challenges. A submarket analysis shows that home market advantages are more deeply rooted in the Western part of Germany and that foreign competitors find a more accessible competitive environment in Eastern Germany. Therefore, East Germany is a superior platform for deploying effective and efficient countervailing strategies. Moreover, we identify a broader rationale to engage early and decisively in untapped but promising markets like China.
\end{abstract}

Keywords: Liability of foreignness, automotive market, multinational strategy, seemingly unrelated regressions

JEL-Classification: F23, L62, M10

1 Centre for European Economic Research (ZEW), Department of Industrial Economics and International Management, P.O. Box 1034 43, D-68034 Mannheim, Germany

${ }^{2}$ Max Planck Institute of Economics, Entrepreneurship, Growth and Public Policy Group, Kahlaische Straße 10, D-07745 Jena, Germany

Corresponding author: Wolfgang Sofka, sofka@zew.de, Tel.:+49-621-1235-181, Fax: +49-621$1235-170$

The authors thank Prof. Dr. Ulrich Kaiser, Dr. Christian Rammer and Prof. Dr. Thorsten Teichert for invaluable comments and discussions. 


\section{Introduction}

"I still hate to buy a foreign car, but the quality and reliability makes it hard not to", this is how the New York Times (Hakim, 2005) describes the attitude of a typical American car buyer. While technological advances (most notably in information and communication technologies) and ideological changes (trade liberalizations, large emerging markets in China and India) translate into enormous business opportunities from globalization (Govindarajan and Gupta, 2001; Gupta and Westney, 2003), we do not live in a borderless world (Ohmae, 1990). Multinational enterprises internationalize their business activities to achieve efficiency (resulting from economies of scale and comparative advantages leading to higher profits on extended markets), learning (through access to localized knowledge) and responsiveness (regarding local customer demand) (Bartlett and Goshal, 1987; Lessard, 2003). Especially the latter has proven difficult. Globalization has ultimately not led to globally homogenous preferences among customers as suggested most prominently by Levitt (1983). As globalization improves income levels, customers look beyond basic daily-life purchases and ask for higher quality products that reflect their culture and personality more deeply, which actually leads to more international diversity in demand, not less (de Mooij, 2000).

Given the intensified competition on international markets (Kleinschmidt and Cooper, 1988), it becomes crucially important for any company to have the necessary organizational system (skills, incentives, processes, communication) in place to compete successfully on foreign markets; or, in other words, to overcome its "liability of foreignness" (Hymer, 1976) when it ventures outside of its home market and faces competitors that are highly adapted to their domestic competitive environment. While several studies have identified the challenges from liabilities of foreignness, practitioners found it difficult to derive countervailing strategies (Mezias, 2002a, 2002b). This study is designed to extend the existing research in two ways. Firstly, we suggest a management tool based on market data that allows managers to estimate their firm's individual degree of liability of foreignness and thereby the previous success of their existing internationalization strategy. Secondly, we establish a strategic framework that puts these estimates in perspective and shows ways for effective strategy optimization. We develop the conceptual framework and apply our concept to a tangible industry case study. Luo et al. (2002) have undertaken a similar endeavor for developing markets. We focus instead on a mature and large market for broader applicability: the German automotive market.

The automotive industry has been at the forefront of internationalization. We estimate the degree of liability of foreignness for the major foreign players on the German car market; or to put it differently, we investigate whether their firm-specific advantages help them in overcoming their liability of foreignness. In essence, we ask: How successful would a foreign company have been on the German market with its models had it behaved as and been considered a domestic one? Obviously, this hypothetical situation cannot be readily observed. Hence, we rely on econometric modeling to control for observed heterogeneity and obtain the real effect of being and behaving like a foreigner on the German market. In contrast with 
previous studies, we do not rely on hypothetical consumer choice situations or sheer volume considerations. Instead, we use the actual turnover a car manufacturer generated on the German car market in the year 2003 for each model, considering all models with significant sales numbers (more than 1,300 in total).

Our analysis focuses on Germany, the third largest car market in the world and by far the largest market in Europe. Its size makes Germany an attractive market for every car producer in the world. However, Germany is a tough competitive environment for every foreign competitor due to its large, entrenched domestic automotive industry and a strong home bias of demanding German customers (Licht et al., 2005). Some evidence points towards a waning importance of this home bias in the USA, the largest market for automobiles in the world (Hakim, 2005; Licht et al., 2005). And in Germany, too, recent history provides a unique opportunity to investigate the dynamic aspects of liabilities of foreignness. Since relevant domestic producers used to be at home only in Western Germany, following reunification in 1990 all competitors started on equal footing in Eastern Germany. By dividing our sample into West and East German customer groups we explore whether West German producers were able to project their home status across the former border or whether, as far as preference goes, East German customers do not distinguish between German and foreign built cars. Finally, we contrast our estimates of the degree of liability of foreignness with the actual importance these customer groups have for different foreign manufacturers in order to identify strategic implications and recommendations.

The paper is organized as follows. The next section presents our conceptual framework. Section three outlines its application on Germany's automotive market and the empirical implementation. In section four we present our results followed by conclusions, strategic assessments and recommendations.

\section{Conceptual framework}

\subsection{The nature of liability of foreignness}

\section{Sources of liabilities of foreignness}

Domestic companies have an advantage over their foreign counterparts because of the intensive accumulation of tacit knowledge in economic, social, legal and cultural conditions in their home country market. In contrast, foreign firms have problems to develop a deep understanding of the host country's sticky unwritten laws, the cultural and social regulations and their impact (Jensen and Szulanski, 2004). Natives have acquired relevant knowledge at no cost as part of their education and can therefore adopt the relevant information more easily, i.e., they know where to look (Mezias, 2002b). This leads to more frequent errors or delayed decisions among foreign companies (Lord and Ranft, 2000). These disadvantages of enterprises operating on foreign markets are known as "liability of foreignness" (Hymer, 
1976). ${ }^{1}$ Liability of foreignness is a relative concept (Hymer, 1976): Enterprises engaging abroad face certain unavoidable costs that companies operating in their own home environment do not. The main source of liability of foreignness in an industry is an interaction of social and cultural components that potentially creates barriers for foreign companies, i.e., to becoming fully integrated into the local flow of information between customers and companies in the host country (Granovetter, 1985; Zaheer and Mosakowski, 1997).

Zaheer (1995) derives the main cost factors underlying liability of foreignness:

- Costs directly related to spatial distance, i.e., travel, transportation, coordination and monitoring over larger distances and different time zones (Gomes and Ramaswamy, 1999; Hitt et al., 1994).

- Costs arising from a lack of roots and experience in the respective local environment, for example in assessing risks (higher learning costs).

- Costs due to a lack of perceived legitimacy in the respective host country (higher reputation-building costs).

- Costs related to domestic restrictions, e.g., restrictions of high technology sales to certain countries (legal restrictions).

In essence, liability of foreignness is a double-edged sword: foreign enterprises are 'strangers in a strange land' (Heinlein, 1961). An obvious point is the host consumers' uncertainty stemming from a lack of knowledge about the foreign company and the quality of the offered product. In addition, foreign companies feel estranged because they miss the relevant tacit knowledge to interpret the daily business in the way natives do (Hymer, 1976). To overcome these disadvantages, multinational enterprises that invest abroad must cultivate their unique mix of assets to adequately compensate for their foreigner status (Caves, 1971).

\section{Country of origin effects}

Marketing literature has devoted a substantial body of literature on the "legitimacy" issues of foreign firms abroad. These "country of origin” studies are not very well integrated in the literature on liability of foreignness. Put simply, the former refer to buyer conceptions that treat the information about the country of origin as a clue regarding product quality, which is the rationale behind labelling products for example as "Made in Germany". While the country-of-origin concept is built around customer perceptions, liability of foreignness is a multinational enterprise concept. Still, both are deeply intertwined.

The relationship between country of origin and consumer product evaluation has been acknowledged in many studies since the 1960s. They indicate that the country of origin does

There has been a recent discussion on the merits of a suggested distinction between the costs of doing business abroad (as an economic concept) and liability of foreignness (as a sociological concept, covering structural, relational and legitimacy issues) (Eden and Miller, 2004; Zaheer, 2002). Our analysis is not designed to add to this specific discussion. 
indeed affect product evaluations (see for example Diamantopoulos et al., 1995; Hsieh, 2004; Nagashima, 1970; Reierson, 1966; Scholler, 1965). Early studies, like Reierson (1966) and Nagashima (1970) found that there exists a strong national bias for domestic products. ${ }^{2}$ Recent studies point towards a more indirect or mitigating country-of-origin effect that could be overcome by other quality cues such as, for instance, product warranties (Chao and Gupta, 1995). This might also explain why they have been considered less important in other studies (Pareja, 2001). Lots of research activities have been devoted to this topic and produced a variety of studies that differ in level of analysis and methodology. While a more in-depth discussion would go beyond the scope of this paper, we recommend an excellent literature review by Bilkey and Nes (1982).

\section{Performance effects}

So far, research has systematically investigated and confirmed the existence of liability of foreignness, most notably Zaheer (1995), DeYoung and Nolle (1996), Hasan and Hunter (1996), Zaheer and Mosakowski (1997) and Miller and Parkhe (2002). A number of empirical studies have shown that multinational enterprises face enduring barriers in foreign countries (Hennart, 1982; Hymer, 1976) and a lack of embededdness (Goshal and Bartlett, 1990; Granovetter, 1985; Zaheer and Mosakowski, 1997) compared to local firms. The most prominent sectoral studies on the topic focus on the banking industry, currency trading and labour lawsuits (DeYoung and Nolle, 1996; Mezias, 2002b; Miller and Parkhe, 2002; Miller and Richards, 2002; Zaheer and Zaheer, 1997). Still, DeYoung and Nolle (1996) add that foreign-owned enterprises may force growth more intensively than profitability.

Some authors have focused on the dynamic aspects of liability of foreignness (Petersen and Pedersen, 2002; Zaheer and Mosakowski, 1997). On the one hand, foreign enterprises seem to learn and adapt to the host country environment with time. On the other hand, their perceived legitimacy in the host country increases, too. Hence, moving operations abroad is more of a marathon than a sprint, i.e., it takes time to compete on the same level as local enterprises. Zaheer and Mosakowski (1997) estimated that it will take more than 15 years for foreign enterprises to overcome the disadvantage of being foreign in the currency trading industry. Therefore, to succeed in competition with local companies, foreign firms need a strong competitive advantage to compensate for the negative effect of liability of foreignness. ${ }^{3}$

\footnotetext{
2 Nagashima, 1970, for example, shows that $80 \%$ of U.S. consumers and $93 \%$ of U.S. businessmen prefer U.S. cars. Japanese consumers that do not associate their home country with high quality in automobile production (in the 1970's) prefer at least to $57 \%$ home made cars.
} 


\subsection{Strategic framework}

\section{Strategic positioning}

The previous section outlined the general drivers and mechanisms behind liabilities of foreignness. Still, we aim at deriving viable management implications as called for by Mezias, (2002a, 2002b). Hence, our results for liabilities of foreignness need to be put into a strategic context. We derive this framework based on the Integration-Responsiveness concept (Bartlett and Goshal, 1989; Doz and Prahalad, 1984; Prahalad and Doz, 1987). It stresses the strategic dilemma of multinational enterprises to balance the conflicting forces of efficient global integration and coordination on the one hand and the need to adapt products, processes and operations to local tastes, attitudes and regulations on the other hand (Eden and Molot, 2002; Rugman and Verbeke, 1998). Global integration is largely propelled by economic, technological and competitive conditions (Doz and Prahalad, 1984). These factors are primarily important multinational customers and competitors, high investment and technology intensity, pressure for cost reductions, universal needs and access to raw materials and energy (Prahalad and Doz, 1987). Local responsiveness is triggered by differences in customer needs or distribution channels, the availability of substitutes, the need for adaptation, market structures or host government demands (Prahalad and Doz, 1987). Achieving legitimacy and reputation is the central rational behind adaptation (Jensen and Szulanski, 2004). The responsiveness vs. integration concept has been empirically tested and expanded (Devinney et al., 2000; Roth and Morrison, 1990). Grein et al. (2001) highlight the importance of an adequate strategic fit between integration and responsiveness as a recipe for success in the automotive industry. Doz et al. (2001) suggest that an intelligent international division of competencies and capabilities might even create additional, "metanational” competitive advantage.

Identifying this optimal strategic blend is challenging since any assessment is subjective and depends on ones perspective within the company. International headquarters will always opt for increased global integration, while local subsidiaries will prefer the freedom to tailor the products to their unique country needs. What is more, integration proponents can largely rely on "hard" data (e.g. savings from cost reductions), whereas responsiveness advocates have to base their arguments on less tangible evidence like host country consumer sentiment (Doz and Prahalad, 1984). We suggest an estimated degree of liability of foreignness to fill this void. It is an adequate measure for the responsiveness a company has achieved within a host country relative to host country rivals. We contrast this position in responsiveness with the importance of a particular market for the company in terms of sales. In essence, we argue that a multinational company faces "push" and "pull" factors when choosing its optimal compromise strategy between global integration and local responsiveness. The importance of a particular market or customer segment for its economic success will push certain strategic choices which can be optimized when considering the pull factors a company has already established through its responsiveness for local tastes. Focusing on the former and ignoring the latter or vice versa will result in suboptimal decisions. Hence, we suggest the following matrix. 
Figure 2.1: Importance-Liability-Matrix

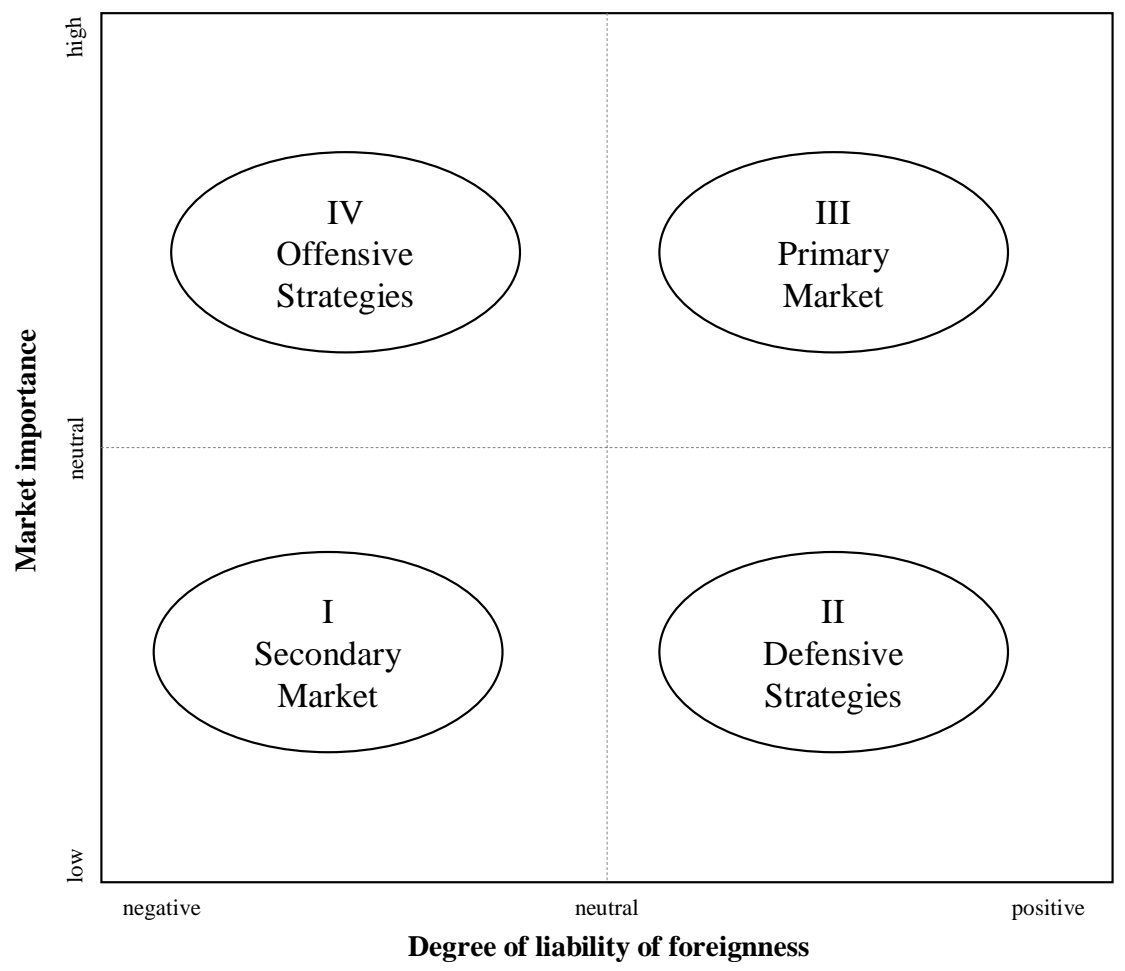

Based on the strategic positions mapped in this matrix we derive strategy recommendations. For matrix segment III we argue that the mix between integration and responsiveness is optimally reflected. The multinational company outperforms its local competitors in terms of responsiveness in a market that becomes crucial to its economic success. The opposite is true for segment I: In comparison, segment I indicates that the company does not match the taste and attitude of its host market. It is still appropriate due to its low importance for the success of the company. However, firms in this quadrant might accept their position as non-core ancillary or simply want to deny rivals an uncontested market in multipoint competition (Chen, 1996; Mezias, 2002a).

The segments II and IV are the more challenging and therefore interesting positions in our matrix. We utilize a construct put forward by Luo et al. (2002) on strategies to deal with liabilities of foreignness. They distinguish between defensive strategies (contract protection, parental control or service, output standardization) and offensive strategies (local networking, resource commitment, legitimacy improvement, input localization). In essence, defensive strategies imply avoiding liabilities of foreignness while offensive strategies actively tackle them. We argue that in matrix quadrant II responsiveness has already been achieved and defensive strategies, which lead to increased global integration, will maximize the pay-offs from the engagement given the relative low importance as a driver for overall sales. Then again, if a company finds itself positioned in matrix segment IV, offensive strategies are called for. The particular market or customer group is vital as a driver for economic success and therefore increasing responsiveness will optimize results. 


\section{A tool for estimating the degree of liability of foreignness}

Section 2.1 made it clear that liability of foreignness is not a tangible concept. It cannot be easily observed and measured; managers cannot be surveyed to estimate its degree. Hence, we suggest an indirect approach. Our concept relies on host market data. This information should be available at a disaggregated level for the actual item of competition, e.g. automotive companies do hardly compete on individual cars but on lines of equally equipped car models. For these items meaningful measures of economic success (typically profits or turnover) are required, as well as central product and company characteristics. The goal is to isolate the effects of liability of foreignness from a variety of other relevant product and company asymmetries. This can be achieved through econometric modelling. The remaining differences in performance between domestic and foreign competitors can be estimated as firm-specific degrees of liability of foreignness. Our approach has several advantages:

- Market data is typically broadly available both for the own company as well as for major competitors.

- The technique relies on benchmark comparisons between individual foreign companies and domestic competitors, instead of hypothetical, normative targets. It allows firm specific identification of best practices.

- Using market data enables us to judge liabilities of foreignness from the most relevant perspective: Through the eyes of the customer.

- We do not rely on subjective opinions or predictions but objective, real-world sales data.

- Our technique delivers value estimations (so called shadow prices) for important company and product characteristics which can subsequently be used to validate the model.

- Our approach can be scaled according to time, skill and resource requirements. Some managers might even opt for simple spreadsheet ordinary least squares regression.

Nevertheless, one should not misinterpret the flexibility of our approach as arbitrary. It follows the comprehensive research framework suggested by Mezias (2002a). The latter is built around a few central pillars which will be reflected in all subsequent conceptual and empirical steps:

- Liabilities of foreignness are broadly defined: Costs that only foreign firms have to bear in the host country or bear disproportionately, including forfeited benefits which are limited to host country firms.

- Controls for other liabilities: The effects of liability of foreignness can only be assessed accurately if they can be separated from other liabilities (age, newness, size, level of globalization or involvement).

- Liabilities of foreignness can only be reasonably evaluated in comparison to domestic firms (which can be multinational themselves) operating in the same host country. 
- Liabilities of foreignness should be analyzed at the firm-level, preferably through a dummy variable.

- Estimations of liabilities of foreignness must control for contextual aberrations which are for example due to regional differences in the host country.

To illustrate this approach we present its application to the German car market. Liability of foreignness has been defined as an entrenched competitive disadvantage for foreign multinationals compared to their host country competitors. Typically, the consequences of this disadvantage should be reflected in a relative shortcoming in profits (Zaheer, 1995). This practice has been criticized for being prone to distortion due to intra-multinational transfer pricing (Mezias, 2002b). Hence, we follow a different route. Given, that the car market success still depends on offering the "right" models, or in other words a successful differentiation strategy (Automobil-Produktion, 2005d), we choose the individual car model (e.g. BMW 325Ci $184 \mathrm{HP}$ ) as our item of investigation. We argue that the turnover generated with any model on the German car market reflects the competitive position of a car producer best. It is clearly preferable to the closely related sales volume (units) or price information. Thus, we investigate how closely a car model fits with German customers' tastes and subsequently their willingness to pay for it. Given the trade off between sales price and volume, we capture this effect comprehensively by using turnovers. Since liability of foreignness is a relative concept, we propose that the differences in turnovers of comparable cars between German and foreign producers can be interpreted as the degree of liability of foreignness. What is more, utilizing this concept and observing actual (not hypothetical) buyer decisions on the German car market allows us to put a quantifiable "price tag" on the degree of liability of foreignness for major international car producers in Germany. This allows comparisons between international competitors. To what degree do their firm specific advantages allow them to balance global standardization and local responsiveness?

\section{Identifying strategic leverage points}

Once the degree of liability of foreignness in a particular host country has been estimated and the strategic position has been established, the question remains on the most efficient targets to implement these strategies. If for example, a company learns from the previous steps of our analysis that its degree of liability of foreignness is high in an important market and offensive strategies are called for, where should it start to intensify its local networking? Which leverage points offer the most efficiency and effectiveness?

We argue that such leverage points can be identified when applying the previously described estimation tool to different sub samples. Given the socio-cultural nature of liability of foreignness and its deeply rooted mechanisms in a country, disruptive changes in a society invalidate the established social network and open chances for newcomers from abroad to develop local embeddedness at equal rates than domestic competitors. These changes must be severe in nature and run much deeper than what some studies have discussed in the context of first mover and follower advantages (see for example Sofka and Schmidt, 2004). Typical drivers of such fundamental changes could be political, economic, technological or demographic in nature. The centres of gravity of these shockwaves can be localized in 
specific regions, customer segments, or urban/rural areas which can subsequently be utilized as steppingstones for the market as a whole. An illustration from our German automotive market case study should clarify this.

Germany offers the opportunity to investigate the dynamic aspects of liability of foreignness, its roots and mechanisms. Before reunification in 1990 the East German car market was largely closed for Western producers and customers were not directly targeted by their marketing efforts. Hence, in Eastern Germany existed a whole regional buyer group within Germany that had little or indirect ties to West German car manufacturers. When the Berlin Wall came down, all automotive producers had a fresh start in this untapped market. While both parts of Germany share some historic, cultural and societal traits and similarities, significant differences in economic structure, behaviour and living conditions remain (see for example Sofka and Schmidt, 2004). Therefore, West German home market advantages could not be readily transferred to the East. Hence, we expect that it is easier for foreign manufacturers to compete with their West German competitors in East Germany where all producers lacked local embeddedness after reunification. We investigate whether West German producers were able to establish their home advantage in the East 13 years after reunification or whether East Germany is still a level playing field for all producers no matter where they come from.

\section{Industry case study: Liability of foreignness on the German car market}

\subsection{The industry context}

The automotive industry is on the forefront when it comes to globalizing production and investments (Nunnenkamp, 2000). Germany is the largest national car market in Europe and the third largest market globally behind the USA and Japan (VDA, 2003). ${ }^{4}$ On the production side, Germany accounted 2004 for almost $12 \%$ of worldwide production (OICA, 2004). ${ }^{5}$ The automotive industry provides more than 770.000 jobs; that is one out of eight employees in the German manufacturing sector (VDA, 2004). The relationship between Germany and the automotive industry is strong and deeply rooted. German customers prefer domestic brands, and local producers benefit predominantly from their sophisticated feedback in refining their products (Licht et al., 2005). Hence, the German car market is an interesting case to investigate liabilities of foreignness. Besides, there are three more general trends in the

$4 \quad$ Germans currently drive more than 44 million passenger cars (ACEA, 2005). They buy roughly 3.2 million new cars annually, which translates into: one out of every five new passenger cars sold in Western Europe has a German buyer (ACEA, 2003). entrenched: Germany had a world production share of 14.4\% in 1960 (Diehl, 2001). 
automotive sector that affect companies competing on foreign markets and should also be felt on in Germany.

Firstly, multinational corporations face the basic dilemma of rationalizing and standardizing their activities and products across countries to boost efficiency while at the same time maximizing turnover by customizing their products to individual host country demands (Doz, 1980). This trade-off between integration and responsiveness (Bartlett and Goshal, 1989; Doz and Prahalad, 1984; Prahalad and Doz, 1987) is especially pronounced in the automotive industry (Grein et al., 2001). The high investments required to develop a new model, substantial fixed costs and long car model life cycles (typically 6 to 7 years) need to be addressed through large output volumes and subsequent economies of scale. However, given relatively diverse tastes across countries for cars (Jürgens, 2003), there is a substantial need for product adaptation, which runs counter to the previously envisioned standardized products. Responsiveness can be achieved at various levels. Khurana and Rosenthal (1997) p. 111 highlight that "customers do not buy only the tangible product itself but a package that includes the product itself, the company, the brand image, the sales interaction, the delivery process, the after-sales service, and the follow-up relationship." Hence, overcoming liability of foreignness in the German car market as early as in the model development process is of critical importance for any foreign competitor that wants to avoid being trapped between the forces of global integration and local responsiveness. ${ }^{6}$

Secondly, modern automotive development and production is highly decentralized and modularized. This trend has reached prominence in the increasing internationalization of automotive value chains (Diehl, 2001). However, there is more than a regional perspective. Through cost cutting efforts, original equipment manufacturers (OEM), the companies that usually control the brand and ship the complete car, outsource more and more responsibilities in $R \& D$ and production of complete modules to their suppliers (Heneric et al., 2005). The average OEM of today contributes only roughly $25 \%$ of value added to the complete car and this downward trend is about to continue (Cleff et al., 2005b). OEM's focus their value adding operations on the body section where the design is most visible to the customer. Nevertheless, leaving the development and production of central modules of a car to supplying companies opens the door for competitors to acquire these parts in equal sophistication and quality while hereby eliminating a source of differentiation from competing OEMs. While mergers and acquisitions in the automotive industry (Caspary et al., 2003; Heneric et al., 2005) have gathered public attention, they reflect only a fraction of the degree of cross company integration. Co-operating with competing companies in the development of new car parts or even complete models is the rule not the exception in the automotive industry. $^{7}$ Automotive magazines already addressed such "twin" car models, like the

6 BMW, for example, located its development team for the new Rolls-Royce Phantom outside of Germany in London, Kensington (Bergfeld and Stahl, 2005). General Motors likewise developed, tested and validated its new Cadillac 2005 CTS model at the Nuerburgring race track in Germany and plans to open its international development centre for compact cars in 2006 in Ruesselsheim, Germany (AutomobilProduktion, 2005a; Cadillac, 2005).

92\% of the parts for the new Toyota Aygo, Citroen C1 and Peugeot 107 are identical (AutomobilProduktion, 2005c). Automobil-Produktion, 2005b lists ten current co-operation projects in the small car segment alone. 
Mitsubishi Colt and the Smart Forfour or the Porsche Cayenne and the VW Touareg, and were still able to identify delicate but noticeable items that made a difference (Autobild, 2005). In conclusion, given the current trends in automotive development and production, differentiating oneself from competitors in the eyes of the customer becomes less tangible, more subtle and more complex. This development makes it harder for foreign competitors to adopt successful host country practises (Mezias, 2002b; Zaheer, 1995) if they lack firmspecific advantages. If they possess these advantages, though, they will find it easier to overcome their liability of foreignness.

Thirdly, we expect a shift in the degree of liability of foreignness due to changes in the regulatory environment. Hymer (1976) argued that one aspect of liability of foreignness would be differential treatment by host governments and that these discriminations would be fairly stable over time. For the European car market, we witness the opposite development. Restrictions on imports, most notably from Japan, have expired or have become obsolete through the WTO and EU enlargement process (Jürgens, 2003; Kaminski and Ng, 2001). What is more, Mezias (2002b) suggests that it is easier for firms to overcome their liability of foreignness if they can learn from host country affiliates. In the case of the automotive industry, these would be primarily domestic distribution, sales and service partners. For a long time, this infrastructure was brand-exclusive in the German car market, e.g. one could not buy a new Volkswagen at a BMW dealership and vice versa. Therefore, foreign competitors had to build their sales network from scratch, and prospective customers found it difficult to compare their offerings directly with domestic competitors in a single showroom. The concept of a car warehouse for all sorts of brands was almost non-existent. The EU Commission abandoned this practise through its Block Exemption Regulation (BER, regulation no. $1400 / 2002)$ in $2002 .^{8}$

\subsection{Defining foreignness}

Obviously, it is crucial to any analysis on liability of foreignness to clearly define who is actually considered a foreigner. This issue appears easy at first glance. Zaheer and Mosakowski (1997) discuss a number of concepts that would indicate whether a company can be considered foreign: location of international headquarters, nationality of the majority of workers (Reich, 1990), share of foreign shareholders, nationality of the largest single shareholder or the perception of a company in a particular country. We will resort to the latter concept. Given the degree of internationalization of the modern automotive value chain, it is difficult to attribute the country of origin to a single nation (Han and Terpstra, 1988). Chueh and Kao (2004) discuss even more detailed decompositions: Country of design, country of parts, country of assembly and country of manufacture. Given limited data availability and the focussed purpose of this study, we follow the example of the World Investment Report (UNCTAD, 2003) and define the traditional home economy or home market in which the company traditionally built and refined its capabilities as our indicator of foreignness.

$8 \quad$ For a more in-depth discussion of these topics see Cleff et al. (2005a), Emanuel (2002) and Koolen et al. (2005). 
Besides, we choose an empirical estimation strategy (described in the following section) that addresses possible adverse effects from this assignment of foreignness. While we are confident that this procedure captures the effect of foreignness most suitably for the purpose of our study, two extreme cases should be briefly addressed. The engagements of General Motors and Ford in Germany run deep and date back to the pre World War II era. General Motors controls Opel since 1929 (the company was founded 1862 by German engineer Adam Opel), and the German branch of Ford was established in 1925. Hence, one could certainly argue that these companies should be considered German (i.e. domestic) instead of foreign. Still, we fear that by doing so, we would severely neglect the internalization activities and subsequently liabilities of foreignness of two of the largest car producers in the world. Accordingly, their home market is considered to be the USA. One other aspect should be pointed out for clarity and transparency. We use brands as a proxy-variable for the producing company. This is certainly a simplifying assumption. One could argue that certain local operations are more independent from international headquarters than others. In the absence of suitable data sources to cover this degree of independence, we rely on the observable brand perspective. Nevertheless, this issue should be kept in mind when interpreting the results. Table 3.1 discloses the complete specification for full transparency.

Table 3.1: $\quad$ Overview on sampled brands and assigned home markets ${ }^{9}$

\begin{tabular}{|l|l|}
\hline Brand & Home market \\
\hline Audi & Germany \\
\hline BMW & Germany \\
\hline Citroen & France \\
\hline Fiat & Italy \\
\hline Ford & USA \\
\hline Honda & Japan \\
\hline Hyundai & South Korea \\
\hline Mazda & Japan \\
\hline Mercedes (Daimler Chrysler) & Germany \\
\hline Nissan & Japan \\
\hline Opel (General Motors) & USA \\
\hline Peugeot & France \\
\hline Renault & France \\
\hline Seat & Spain \\
\hline Skoda & Czech Republic \\
\hline Smart & Germany \\
\hline Toyota & Japan \\
\hline Volkswagen & Germany \\
\hline Volvo & Sweden \\
\hline & \\
\hline
\end{tabular}

$9 \quad$ Brands with markets shares below 1.5\% in Western Europe 2003 excluded. 


\subsection{Defining quality}

So far we have used the term "comparable" car to stress the point that we can only estimate the degree of liability of foreignness once we have controlled for defining quality characteristics of a car model. However, cars are complex products. They comprise several functions: Speed, safety, security, entertainment, individuality, reputation, social status, to name a few. Buyers can only purchase the whole bundle when purchasing a car. Disentangling those value drivers through the eyes of the customer gives some valuable insight into what exactly people cherish in their cars. The idea is to treat the individual car purchase not as a black box product but instead as a bundle of functional components that in combination generate enough value for the individual customer to justify the price (Licht et al., 2005). This challenge has largely been covered in marketing research and hedonic price analysis. While these two bodies investigate other topics than we do, we would like to learn from their experience in modeling relevant quality characteristics.

Marketing research in the field focuses largely on consumer preferences. Consumers have individual preferences through which they evaluate the quality of a car, which enables them to decide if and what kind of car they should buy. Hence, it is important for car manufacturers to produce cars that meet these preferences. The prevailing methods employed to evaluate the preferences are conjoint analyses and joint stated/revealed preferences models (Berkovec and Rust, 1985; Brownstone et al., 2000; Bunch et al., 1993; Train and Sonnier, 2002). The dominant quality characteristics in these studies are price, performance, engine type, convenience and operating costs (Brownstone et al., 2000; Bunch et al., 1993).

The basic idea behind hedonic price analysis lies in the assumption that changes in prices can only be correctly assessed once they have been adjusted for changes in quality. ${ }^{10}$ Based on the hypotheses that goods are valued for their value-creating characteristics, hedonic prices are defined as the implicit prices of these attributes (Rosen, 1974). Basics in the work with hedonic prices arise from studies of Court (1939) and Griliches (1961). Griliches (1961) found that almost all of the recorded rise in the new automobile component of the Consumer Price Index (between 1954 and 1960) could be attributed to substantial improvement in the quality of automobiles. This hedonic approach has been used in recent years in the automotive sector to investigate a variety of research topics (see for example Goldberg and Verboven, 2001, 2004; Verboven, 1998, 2002). Their prevailing goal has been to achieve segmentation in the car market largely based on performance and size.

Based on the discussion presented above we derive four broad quality factors that influence the product evaluation of prospective car buyers: performance, economic and ecological efficiency, safety and convenience/amenity.

$10 \quad$ For a more in-depth description of the concept see Berndt (1991). 


\section{$4 \quad$ Empirical analysis}

\subsection{Data}

We use a cross section dataset for the year 2003 which we generated by combining three data sources. The core of our dataset was provided by the Kraftfahrt-Bundesamt (KBA, Federal Bureau of Motor Vehicles and Drivers) which is uniquely positioned for this task since it is, among other things, the German authority for approving all vehicle types in Germany. It publishes the „New passenger car registrations by regional and contextual criteria“"11 statistics annually. It contains information on new registrations by car model as defined in official German statistics. Besides, these numbers are also provided for nonexclusive sub-groups: state, age, gender, corporate status. We merged this dataset with the information from another KBA statistical publication: Directory of passenger car manufacturers and types. ${ }^{12}$ This allowed us to add basic quality characteristics to our dataset, e.g. type of fuel, engine power. Thirdly, we enriched our dataset with 2003 price and more specific quality features as provided by a leading German car evaluation company, EurotaxSchwacke. This combination of volume information provided by KBA and price information provided by EurotaxSchwacke enables us to generate our unique indicator of success: turnover per car model. The pricing information for new cars reflects list prices which do not incorporate any rebates, trade-ins ${ }^{13}$ or throw-ins. ${ }^{14}$ These arrangements are quite common in car purchasing. Albeit, in the absence of more detailed price information, we are confident that these list prices are the most reliable proxy variable available. Besides, we enrich our dataset with advertising expenditures published by automotive intelligence provider B\&D Forecast GmbH and Germany's leading automobile assistance association ADAC (ADAC-AutomarxX, 2003). ADAC also provided us with an environmental friendliness ranking EcoTest (ADAC, 2004b). Additionally, we use global turnover and R\&D expenditure data from the EU industrial R\&D investment scoreboard report (European Commission, 2004).

Our matched dataset contains all 1,866 car models, including 584 of German car manufacturers and 1,282 of foreign automobile manufacturers, sold on the German car market in 2003. Liability of foreignness is a concept specifically derived for multinational enterprises. Hence, we limit our sample to foreign manufacturers for which we can safely assume that they can actually be considered multinational and have the necessary sales

\footnotetext{
11 „Neuzulassungen von Kraftfahrzeugen und Kraftfahrzeuganhängern nach Regional- und Sachmerkmalen.“

$12 \quad$ „Verzeichnis der Hersteller und Typen von Personenkraftwagen.“

13 The customer receives a more generous offer for her used car from the dealership if she decides to buy a new one there.

14 The dealership keeps the price for a particular car offer unchanged but enhances its equipment, e.g., by adding door mats or service vouchers.
} 
infrastructure in place. As a result we consider only foreign producers with a market share of 1.5\% in Western Europe which equals roughly 200,000 units sold (ACEA, 2003). Accordingly, our dataset contains all producers with a German home market ${ }^{15}$ and the following foreign car manufacturers: Citroen, Fiat, Ford, Honda, Hyundai, Mazda, Nissan, Opel, Peugeot, Renault, Seat, Skoda, Toyota, Volvo. Due to this restriction and limitations in data availability our final dataset has 1,383 observations (487 German and 896 foreign models).

\subsection{Variables}

Given the theoretical constructs presented so far, the following section describes how we actually operationalized them in our study. The dependent variable is turnover with a particular car model (in logs). We derive this value as the product of units sold and list price. Especially the latter should be interpreted carefully since it can only be considered a proxy variable and is generally higher than typical sales prices which are lowered through rebates and trade-ins. As a result, the reported turnover overstates actual sales. Nevertheless, in the absence of more detailed price information and in line with most hedonic price analyses presented before, we are confident that they provide credible information and induce no bias. We rely also on the experience of several authors from hedonic price analysis by choosing the logarithmic form. Besides, it should be emphasized that we will only consider new car sales, which is the industry standard. Competition from used car segments is therefore excluded. In the second step of our analysis we will use the sales volume numbers from West and East German $^{16}$ car buyers separately. ${ }^{17}$

To comply with the desirable research design proposed by Mezias (2002a) and to free our estimations on liability of foreignness from the influence of other liabilities we add several control variables. To account for liabilities of size and internationalization, we include the share of turnover in Germany on global turnover (gturn). ${ }^{18}$ To control for different approaches in marketing and R\&D we use total advertising expenditures in Germany (media) and the global share of $R \& D$ investments on turnover (rndonturn) respectively. Liabilities of newness

15 Porsche is excluded due to data availability.

16 This includes the following states: Berlin, Brandenburg, Sachsen, Sachsen-Anhalt, MecklenburgVorpommern, Thüringen.

To be precise, we can only observe whether a car was sold in West or East Germany, not where the buyer lives. Still, in the absence of more detailed data and given the dense dealership infrastructure across Germany we are confident that we capture the regional effect correctly.

18

To be precise we calculate the share of German car sales (based on list prices) on global turnover. The latter does certainly also include revenues from other sources like financing and brand licensing. Hence, the variable can only be considered a proxy. 
are addressed through the number of months a particular car model has been on the German market (mtime). ${ }^{19}$

To ensure that we do not compare apples and oranges, we need to control for differences in car quality. Naturally, some quality features that made a difference in previous studies are now considered standard equipment in a modern car (e.g. air conditioning), or even mandatory by law (e.g. immobilizer systems). Hence, choosing adequate instrument variables that reflect our quality concepts and still allow qualified empirical analysis in the dynamic automotive context is a challenging task. We utilized the following quality features which will be outlined briefly to provide full transparency:

- Performance: Engine power measured in kilowatt (in logs: lnkw) and its squared term (sqlnkw). By including the latter we want to test for an inverse u-shaped relationship between performance and turnover. We reason that neither especially low powered car models would generate an optimal combination of price and volume (hence turnover), nor models with very strong engines.

- Economic and ecological efficiency: For environmental friendliness we include the weighted average of a company's EcoTest ranking (env) ${ }^{20}$ and a dummy variable indicating whether the model runs on diesel fuel or not (diesel). Diesel engines have become very popular in Germany. Four out of ten new registrations run on diesel (VDA, 2004). This is mostly due to the increased fuel efficiency of modern diesel engines and a tax incentive scheme that implies higher initial fix costs and lower variable fuel costs. Besides, we include the loss in value in the first year (normalized per brand) as an indicator for value stability (tloss).

- Safety: We operationalized this concept through the number of airbags (airbag). While a driver airbag is almost a standard in modern cars, differences arise in how many other passengers are protected by airbags and from how many possible impact directions. The maximum in our sample is eight airbags.

- Convenience/amenity: This concept is measured by two dummy variables, indicating whether the interior of the car is more luxuriously decorated with wood (interior) and whether it possesses a navigation system (navi). Additionally, we introduce two dummy variables which capture the basic shape of the car model, i.e. whether it is a convertible (cabrio) or a station wagon (swagon).

We did not include vehicle class variables, e.g. lower middle class. We investigated the classifications offered by ADAC and KBA. While they are not totally based on engine power

19 Companies have to apply for a general production permit at the KBA if they want to sell their product on the German market. We consider the date of this production permit a reliable proxy variable for market entry.

The EcoTest ranking is constructed by ADAC as a composite point score of emissions and fuel efficiency. A car model can achieve 100 points at best. Toyota achieved the highest score of 89 with its hybrid powered Prius model. 
this strong relationship made it impossible for us to use both of them simultaneously in the empirical implementation. Therefore, one should bear in mind that the variables for engine power also capture the effects of market segmentation when interpreting the results. Finally, we added for each of the fourteen foreign brands under consideration a dummy variable as proposed by Mezias (2002a). Their coefficients will be the focal point of interest in all following discussions and conclusions. The brands are Peugeot, Renault, Citroen, Nissan, Toyota, Ford, Opel Fiat, Seat, Hyundai, Skoda, Volvo, Mazda and Honda. The reference groups in all further estimations are the car models with German brands.

\subsection{Descriptive statistics}

The following section gives a brief overview of the average car characteristics and the differences between German and foreign manufactured cars. A more detailed and complete list of the means and standard deviations for the variables used in this study is summarized in Table 7.1 in the annex.

Judging from our central success indicator, turnover per car model, German manufacturers have a better performance than foreign ones. The average turnover realized by German manufacturers ( $79.5 \mathrm{mn} €$ ) is more than double the average turnover of foreign producers (31.9 mn €). The difference is high for business consumers, but relatively low for young and East German buyers. Then again, the German market is more crucial for domestic producers (indicated by its share on global turnover). German and foreign producers are far more equal when it comes to how much they spend on advertising in Germany. The same can be said for the "age" of domestic and foreign car models since market introduction. However, there are differences in $R \& D$ intensities. On a global scale, German producers invest a higher share of turnover in R\&D (4.74\%) than their foreign counterparts (4.01\%).

With an eye on performance, the average German car sold has a stronger engine (125 kw) than foreign ones (91 kw). The former also have a slight advantage when it comes to environmental friendliness but the difference is less pronounced. This is not the result of German manufacturers offering more diesel fuelled cars. Roughly a third of the models in our sample drive on diesel fuel and these shares are almost identical for both German and foreign brands. Then again, foreign car models experience a slightly higher value loss during the first year.

When it comes to safety aspects (measured as the number of airbags) German models are only slightly ahead of their foreign competitors. Interestingly enough, we find quite the opposite when it comes to convenience. Foreign models have more often a navigation system, here used as indicator for convenience: $6 \%$ of foreign models offer such a system while only $2 \%$ of the German models do. Still, German models dominate on the luxury side. They have more frequently luxurious interior decoration and are more often sold as convertibles. 


\subsection{Econometric model and method}

At the outset of the empirical part of our analysis we estimate an ordinary least squares (OLS) regression applying the following model:

$$
\begin{aligned}
& \ln \left(q_{i} \times p_{i}\right)=\beta_{0}+\sum_{j=1}^{l} \beta_{j} \times X_{i j}+\sum_{c=1}^{r} \beta_{c} \times D_{i c}+\varepsilon_{i} \\
& \text { where } \\
& q_{i}: \text { Quantity sold of model } i \\
& p_{i}: \text { Price in euroof model } i \\
& X_{i j}: \text { Quality characteristic } j \text { of model } i \\
& D_{i c}: \text { Foreign producer dummy c of model } i
\end{aligned}
$$

In the second step we estimate separate regressions for West and East German customer groups. The purchasing decisions of both groups share common factors. To model this link between the groups adequately, we use seemingly unrelated regressions (SUR) as proposed by Zellner (1962). Within our empirical framework, seemingly unrelated regressions are superior to separate OLS models. The SUR procedure permits more than one equation with correlated disturbances. This correlation across error terms provides links which can and should be exploited. Estimating two equations simultaneously facilitates a more complete usage of the available information. In essence, each equation holds information on factors that influenced the decision in the other buyer group, too. Estimating these equations simultaneously utilizes this information for the complete system. ${ }^{21}$

Hence, the complete specification for step two is

$$
\begin{aligned}
& \ln \left(q_{\text {iwest }} \times p_{i}\right)=\beta_{0 \text { west }}+\sum_{j=1}^{l} \beta_{\text {iwest }} \times X_{i j}+\sum_{c=1}^{r} \beta_{\text {cwest }} \times D_{i c}+\varepsilon_{\text {iwest }} \\
& \ln \left(q_{\text {ieast }} \times p_{i}\right)=\beta_{\text {oeast }}+\sum_{j=1}^{l} \beta_{\text {jeast }} \times X_{i j}+\sum_{c=1}^{r} \beta_{\text {ceast }} \times D_{i c}+\varepsilon_{\text {ieast }} \\
& i=1, . ., N \\
& \operatorname{cov}\left(\varepsilon_{\text {iwest }}, \varepsilon_{\text {ieast }}\right) \neq 0 \\
& \text { where } \\
& q_{i \text { west }}: \text { Quantity sold of model } i \text { in West Germany } \\
& q_{\text {ieast }}: \text { Quantity sold of model } i \text { in East Germany } \\
& p_{i}: \text { Price in euro of model } i \\
& X_{i j}: \text { Quality characteristic } j \text { of model } i \\
& D_{i c}: \text { Foreign producer dummy c of model } i
\end{aligned}
$$

$21 \quad$ For more details see Griffiths et al. (1992) or Wooldridge (2002). 


\section{$5 \quad$ Results and discussions}

Our empirical analysis yields some interesting insights. Table 5.1 presents the results. Our research design allows us to interpret the coefficients of the included dummy variables as the average turnover disadvantage in per cent relative to a comparable German car model. The coefficients of all included company dummy variables enable us therefore to quantify the degree of liability of foreignness as defined in this study. In the conceptual part of this analysis we have frequently highlighted the dangers of comparing apples with oranges and misinterpret other deficiencies as liabilities of foreignness. Therefore, the control variables that have entered our estimation due to this rationale should be outlined first before we get to the individual company results.

Table 5.1: OLS regression results of step 1 on the total turnover with a particular car model

Definitions Variable $\begin{array}{r}\text { Lnturnover } \\ \text { Coefficient }\end{array}$

Robust Std. Error

\begin{tabular}{|c|c|c|c|}
\hline \multicolumn{4}{|l|}{ Producers } \\
\hline Car model from Ford (Dummy) & ford & 0.343 & $(0.333)$ \\
\hline Car model from Opel (Dummy) & opel & 0.405 & $(0.307)$ \\
\hline Car model from Peugeot (Dummy) & peugeot & 0.016 & $(0.278)$ \\
\hline Car model from Citroen (Dummy) & citroen & 0.072 & $(0.328)$ \\
\hline Car model from Renault (Dummy) & renault & 0.161 & $(0.298)$ \\
\hline Car model from Fiat (Dummy) & fiat & $-1.526 * * *$ & $(0.318)$ \\
\hline Car model from Seat (Dummy) & seat & $-0.814^{*}$ & $(0.419)$ \\
\hline Car model from Skoda (Dummy) & skoda & 0.453 & $(0.570)$ \\
\hline Car model from Volvo (Dummy) & volvo & $-1.405^{* * *}$ & $(0.293)$ \\
\hline Car model from Toyota (Dummy) & toyota & 0.620 & $(0.417)$ \\
\hline Car model from Nissan (Dummy) & nissan & -0.063 & $(0.337)$ \\
\hline Car model from Mazda (Dummy) & mazda & $-0.693^{*}$ & $(0.407)$ \\
\hline Car model from Honda (Dummy) & honda & 0.727 & $(0.534)$ \\
\hline Car model from Hyundai (Dummy) & hyundai & $-1.915 * * *$ & $(0.637)$ \\
\hline \multicolumn{4}{|l|}{ Controls } \\
\hline Share of German sales on global turnover & gturn & $0.165 * * *$ & $(0.046)$ \\
\hline Media expenditures & media & $-0.001 * * *$ & $(8.820)$ \\
\hline Share of R\&D investments on turnover & rndonturn & $-0.489 *$ & $(0.255)$ \\
\hline Number of month since market introduction & mtime & $-0.056 * * *$ & $(0.004)$ \\
\hline Kilowatts of engine power in logs & $\operatorname{lnkw}$ & 1.905 & $(1.962)$ \\
\hline Squared kilowatts of engine power in logs & sqlnkw & -0.284 & $(0.208)$ \\
\hline $\begin{array}{l}\text { Weighted average of environmental } \\
\text { friendliness ranking per company }\end{array}$ & env & 0.009 & $(0.009)$ \\
\hline Car model drives on diesel fuel (Dummy) & diesel & 0.098 & $(0.104)$ \\
\hline Normalized value loss in first year per company & tloss & $-0.052 * *$ & $(0.026)$ \\
\hline Number of airbags & airbag & $0.107 * * *$ & $(0.034)$ \\
\hline \multicolumn{4}{|l|}{ Car model has luxurious (e.g. wood) } \\
\hline interior decoration (Dummy) & interior & -0.113 & $(0.105)$ \\
\hline Car model has a navigation system (Dummy) & navi & 0.086 & $(0.184)$ \\
\hline Car model is a convertible (Dummy) & cabrio & 0.157 & $(0.192)$ \\
\hline Car model is a station wagon (Dummy) & swagon & 0.158 & $(0.128)$ \\
\hline Constant & constant & $16.719 * * *$ & $(4.577)$ \\
\hline \multicolumn{2}{|l|}{ Observations } & 1,383 & \\
\hline \multicolumn{2}{|l|}{$\mathrm{F}(28,1354)$} & 17.04 & \\
\hline \multicolumn{2}{|l|}{ Prob $>$ F } & 0.000 & \\
\hline
\end{tabular}




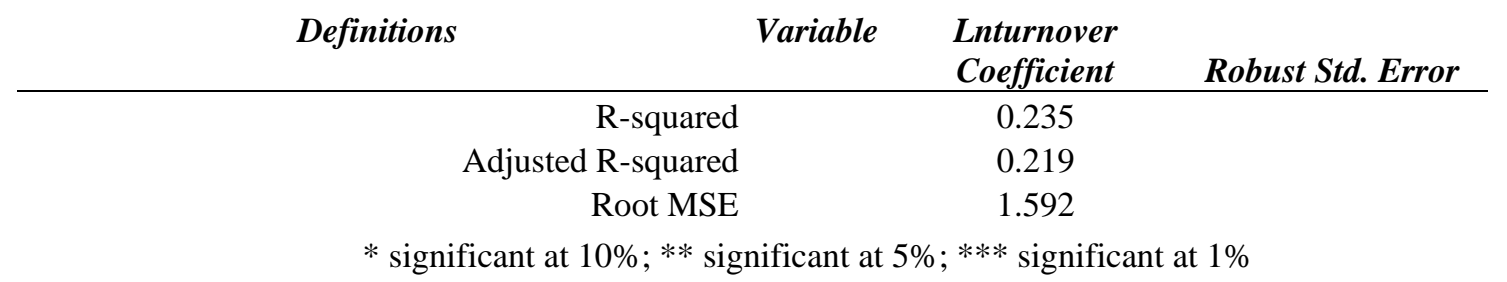

First of all, we find that the importance of the German market for global sales is positively linked to the success of individual car models. This result is fully in line with Doz and Prahalad (1984); Prahalad and Doz (1987). We suggest that German customers are simply becoming too important to ignore. Interestingly enough, the overall advertising expenditures of any producer influence sales negatively. We cannot observe advertising for a particular car model and it would therefore be farfetched to conclude that ad campaigns are per se useless or even counterproductive. Besides, an important argument for increased advertising expenditures is to balance weaknesses in sales. Considering the negative effect of $R \& D$ investments on model turnover we argue that these expenditures are necessary investments into the future and tie up resources in the short run while providing long term competitive potentials. Besides, the age of car models makes a significant difference for success. We find that customers prefer car models that are more up to date and consequently reflect their expectations for a modern car more adequately. Prospective customers may delay their buying decisions and instead wait for the new model to arrive. Such an announcement effect propels sales once the new model has finally arrived.

Interestingly enough, we find that few of our control variables for car quality make a significant difference in turnover. They play only a secondary role within our research framework but the lack of significant impacts is still noteworthy. With respect to car performance we find that the individual variables (lnkw and sqlnkw) are not significant but a Wald test reveals that they are jointly significant. Hence, our expected inverse u-shaped relationship between engine power and turnover is confirmed. A better equipped engine makes a car model more attractive on the German market but only up to a certain threshold. Turnover declines beyond this point. We argue that high powered engines might justify higher prices but that they loose at the same time the appeal of the broader market and therefore sacrifice sales volumes. This underscores the strength of our turnover concept compared to price based or unit based analyses. Besides, few other quality features show a significant impact. We suggest that engine power effectively provides the central segmentation between our car models, e.g. between a car in the micro class and one in the middle class. Companies compete mostly within these classes but not between them, e.g. a customer interested in a Renault Twingo will hardly compare it to a Mercedes S-Class.

Value stability and car safety still make a difference in model turnover. Customers reward car producers that produce lasting superior quality which translates into higher resale prices. Put differently, if prospective customers sense that their investment into a particular new car model will rapidly decline, they will go shopping elsewhere or demand deep discounts (both factors reduce our turnover measure). This rapid devaluation trend may be a symptom with deeper roots: Some models may have a reputation for bad quality and subsequent frequent and costly repairs, they could be totally out of style or unfit for looming regulations. Then again, customers are willing to buy car models with superior safety features (as captured by the 
number of airbags). We argue that passenger safety is at the very heart of what customers expect from a modern car, no matter whether they are shopping for an Opel Corsae or BMW X5. They may be more inclined to do without luxury or convenience features (like a navigation system), but they accept no compromises in protection.

This leads us to the focal point of this phase of the analysis: The coefficients of the dummy variables for the foreign producers and hence their degree of liability of foreignness. First of all, it should be emphasized that relying on the research design developed by Mezias (2002a) enhanced the quality of our results. Otherwise we would have for example misinterpreted a liability of newness as a liability of foreignness. Focusing on these estimates we find that by and large foreign car manufacturers face no general liability of foreignness on the German car market or have compensated it by firm specific advantages. It is noteworthy though, that while most foreign producers compete on equal footing with their German counterparts none has significantly outperformed them. The results are mixed and if there is a significant degree of liability of foreignness it is firm-specific. As discussed earlier, the American producers Ford and General Motors (Opel) have a long term commitment in Germany and it pays off. French producers (Peugeot, Citroen, Renault) face also no liability of foreignness. However, there is a mismatch between what German car buyers expect and what Southern (Fiat, Seat) and Northern European (Volvo) manufacturers offer. Fiat pays on average 1.5\% of typical model turnover for its liability of foreignness, Volvo $1.4 \%$. The result for Seat is a moderate $0.8 \%$ but still interesting. Seat is part of the German Volkswagen Group and can rely on the group's domestic infrastructure. Therefore, one might argue that this primarily explains its lower degree of liability of foreignness. Then again, the same can be said for Skoda but it has managed to avoid liabilities of foreignness. Generally, Japanese producers are also not affected by liabilities of foreignness with the exception of Mazda which has a mild $0.7 \%$ turnover disadvantage. South Korean producer Hyundai faces the most pronounced degree of liability of foreignness with almost $2 \%$. In conclusion, we can neither simply reject nor confirm our first hypothesis. A more in-depth investigation is warranted which has been conducted in the second step of our analysis.

The rationale for this second stage of the empirical investigation has been to exploit the unique opportunity from re-unification to investigate dynamic aspects of liabilities of foreignness on the German car market. Hence, we estimate a seemingly unrelated regression model for West and East German customers. First of all we find considerable degrees of correlation between the error terms of the two individual regressions (0.914). Thus, our estimation procedure did in fact produce superior results to estimating two separate OLS regression. The results are summarized in Table 5.2.

We briefly address the control variables. Most of them are in line with the findings for all of Germany. Still, few differences remain and these will be our primary focus. In line with the earlier discussion we argue that engine performance provides the central segmentation in both markets. $^{22}$ A diesel powered engine makes a car more attractive in West Germany while East

$22 \quad$ In East Germany lnkw and sqlnkw are individually significant. In West Germany they are jointly significant (Wald test). 
Germans dislike it. What is more, the basic design of a car model makes a more significant difference in East than in West Germany: East Germans are attracted by station wagon models while the opposite is true for convertibles.

Table 5.2: $\quad$ Estimation results from seemingly unrelated regression West and East Germany

\begin{tabular}{|c|c|c|c|c|}
\hline Region & $\begin{array}{c}\text { West } \\
\text { Coefficient }\end{array}$ & $\begin{array}{c}\text { Robust Std. } \\
\text { Error }\end{array}$ & $\begin{array}{c}\text { East } \\
\text { Coefficient }\end{array}$ & $\begin{array}{c}\text { Robust Std. } \\
\text { Error }\end{array}$ \\
\hline \multicolumn{5}{|l|}{ Producers } \\
\hline ford & 0.382 & $(0.368)$ & 0.221 & $(0.312)$ \\
\hline opel & 0.501 & $(0.323)$ & 0.103 & $(0.274)$ \\
\hline peugeot & -0.004 & $(0.284)$ & 0.109 & $(0.241)$ \\
\hline citroen & 0.013 & $(0.363)$ & 0.304 & $(0.308)$ \\
\hline renault & 0.015 & $(0.295)$ & $0.508 * *$ & $(0.250)$ \\
\hline fiat & $-1.532 * * *$ & (0.323) & $-1.543 * * *$ & $(0.274)$ \\
\hline seat & $-0.977 * *$ & $(0.438)$ & -0.200 & $(0.371)$ \\
\hline skoda & 0.095 & $(0.599)$ & $1.584^{* * *}$ & $(0.508)$ \\
\hline volvo & $-1.461 * * *$ & $(0.343)$ & $-1.175 * * *$ & $(0.290)$ \\
\hline toyota & 0.617 & $(0.470)$ & 0.647 & $(0.398)$ \\
\hline nissan & -0.230 & (0.399) & 0.408 & $(0.338)$ \\
\hline mazda & $-0.835 *$ & $(0,446)$ & -0.114 & $(0.378)$ \\
\hline honda & 0.661 & $(0.620)$ & $1.206 * *$ & $(0.525)$ \\
\hline hyundai & $-2.138 * * *$ & $(0.639)$ & $-1.351^{* *}$ & (0.541) \\
\hline \multicolumn{5}{|l|}{ Controls } \\
\hline gturn & $0.174 * * *$ & $(0.049)$ & $0.137 * * *$ & $(0.042)$ \\
\hline media & $-0.000 * * *$ & $(0.000)$ & $-0.000 * * *$ & $(0.000)$ \\
\hline rndonturn & $-0.497 *$ & $(0.261)$ & $-0.514 * *$ & $(0.221)$ \\
\hline mtime & $-0.061 * * *$ & $(0.004)$ & $-0.045 * * *$ & $(0.004)$ \\
\hline $\operatorname{lnkw}$ & 1.342 & (1.957) & $4.065 * *$ & (1.659) \\
\hline sqlnkw & -0.215 & $(0.213)$ & $-0.543 * * *$ & $(0.180)$ \\
\hline env & 0.008 & $(0.010)$ & 0.010 & (0.009) \\
\hline diesel & 0.199* & $(0.103)$ & $-0.233 * * *$ & $(0.087)$ \\
\hline tloss & $-0.051^{*}$ & $(0.029)$ & $-0.061^{* *}$ & $(0.024)$ \\
\hline airbag & $0.100 * * *$ & $(0.036)$ & $0.132 * * *$ & $(0.030)$ \\
\hline interior & -0.139 & (0.114) & -0.020 & $(0.096)$ \\
\hline navi & 0.087 & $(0.245)$ & 0.153 & $(0.208)$ \\
\hline cabrio & 0.214 & $(0.211)$ & $-0.318^{*}$ & $(0.179)$ \\
\hline swagon & 0.172 & $(0.134)$ & $0.191 *$ & $(0.114)$ \\
\hline constant & $17.825^{* * *}$ & $(4.511)$ & $10.088 * * *$ & $(3.824)$ \\
\hline Observations & 1,383 & & 1,383 & \\
\hline Chi2 & 441.21 & & 389.94 & \\
\hline Prob > Chi2 & 0.000 & & 0.000 & \\
\hline R-squared & 0.242 & & 0.220 & \\
\hline RMSE & 1.674 & & 1.419 & \\
\hline
\end{tabular}

The results for our foreign firm dummies on the two markets yield some interesting implications. In essence, we find two major patterns in the data. First, outperforming domestic competitors can only be realistically achieved in Eastern Germany. Secondly, liabilities of foreignness are largely incurred in Western Germany. In more detail, we identify four observed archetypes: No liabilities, East and West liabilities, only Western liabilities and Eastern leverages. Figure 5.1 summarizes our results. 
Figure 5.1: Locus of advantage/disadvantage from liabilities of foreignness

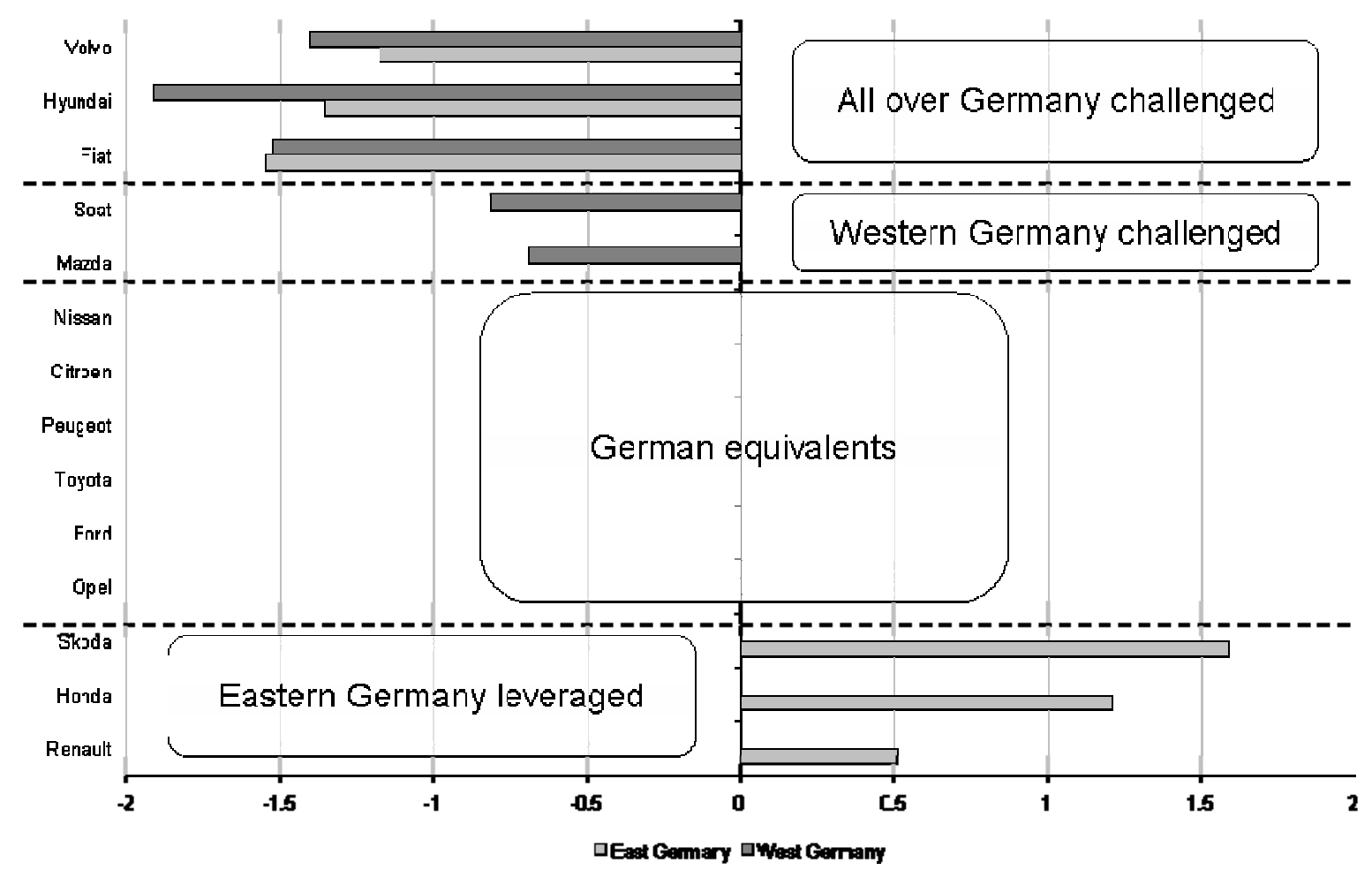

The majority of the analyzed car manufacturers face no liability of foreignness in neither West nor East Germany. For Opel and Ford we did expect such results (see chapter 3.2). Peugeot, Citroen, Nissan and Toyota compete also on the same level as German counterparts. These cases demonstrate that it is possible for foreign enterprises to overcome disadvantages abroad and act successfully vis-à-vis German competitors in West and East Germany. These companies realized an optimal trade-off between integration and responsiveness (Bartlett and Goshal, 1989; Prahalad and Doz, 1987).

The troubling effects identified in step one of our analysis for Fiat, Volvo and Hyundai, are truly unanimous across German. The products of these manufacturers do not meet customer preferences in both sub markets. In the case of Fiat this might not be entirely due to design mismatches but also to quality demands of German customers. The Italian producer has found itself in the bottom region of automotive break-down statistics (ADAC, 2004a). While home market customers in Italy may be more inclined to tolerate certain issues, German customers demand a discount in price or they react with reluctance which translates in lower sales volumes. We measure both effects in our study. The only South Korean producer in our sample, Hyundai, has the most consistent liabilities of foreignness among customer groups. It's 2.1\% turnover disadvantage among West German buyers is the highest estimated degree of liability of foreignness. East German customers are still critical but relatively more sympathetic towards Hyundai (-1.4\%). Finally, Volvo faces a significant challenge in both markets. In this case it might be due to a more focused sales strategy (e.g. business customers) and the strategic portfolio management of its parent company Ford. Ford has been identified to be free of liabilities of foreignness. We will return to strategic implications in the subsequent chapter. 
Seat and Mazda belong to the group of companies that face only Western liabilities. The regression results for these companies show moderate levels of liability of foreignness for the Western German customer group but none in East Germany. This is a troubling sign for Mazda since all other Japanese producers have achieved more promising positions. Evidently geographical distance is not a valid concept for liabilities of foreignness of Japanese car producers in Germany. Apparently, Japanese producers are able to understand what German customers want and deliver it in their products. Mazda should benchmark its products, services and infrastructures against more successful Japanese rivals. Seat is another interesting case to which we will return shortly.

Honda, Skoda and Renault use their firm specific capabilities to outperform domestic counterparts in the East German car market. This is a remarkable achievement for foreign producers. Still, it remains localized in Eastern Germany and (as for now) cannot be readily transferred to West Germany where the grip of domestic competitors on their home market appears to be more entrenched. In this context it is a worthwhile exercise to compare Skoda and Seat. Both are part of the German Volkswagen-Group and should hence benefit from their parent's embeddedness. Seat belongs to the group of enterprises facing only Western liabilities while Skoda shines. It outperforms its German rivals significantly (1.6\%) with Eastern German customers. Since Skoda has access to Volkswagen's extensive dealership network it finds it easier to have its cars directly compared to German Volkswagen brands. We argue that Eastern German buyers might regard Skoda as the better price-qualtiycombination when comparing it directly with similar offerings from German brands. Besides, due to re-unification in 1990 all car companies (German and foreign) started with equal footing in the Eastern German market and had no entrenched customer relationships from marketing or local production. This is not true for Skoda which was already a household name from GDR times.

In conclusion, we did so far identify regional leverage points to address liabilities of foreignness. A foreign car producer facing these disadvantages in Germany would find it generally easier to overcome them in the Eastern part of Germany. Still, the question remains whether the benefits from those investments are worth the investments. The subsequent chapter will address this issue and turn our results into strategy recommendations.

\section{Conclusion}

The previous chapter outlined our estimation results. At this point we want to put them into perspective and derive strategic implications. Thus, we return to the Importance-LiabilityMatrix outlined in section 0. It contrasts the degree of liability of foreignness (horizontal axis) with the importance of a particular customer group for sales in Germany (vertical axis). We present the Eastern and Western German customer groups (Figure 6.1, Figure 6.2) to underscore the usefulness of this construct. 
Figure 6.1: Importance-Liability-Matrix for East German customers

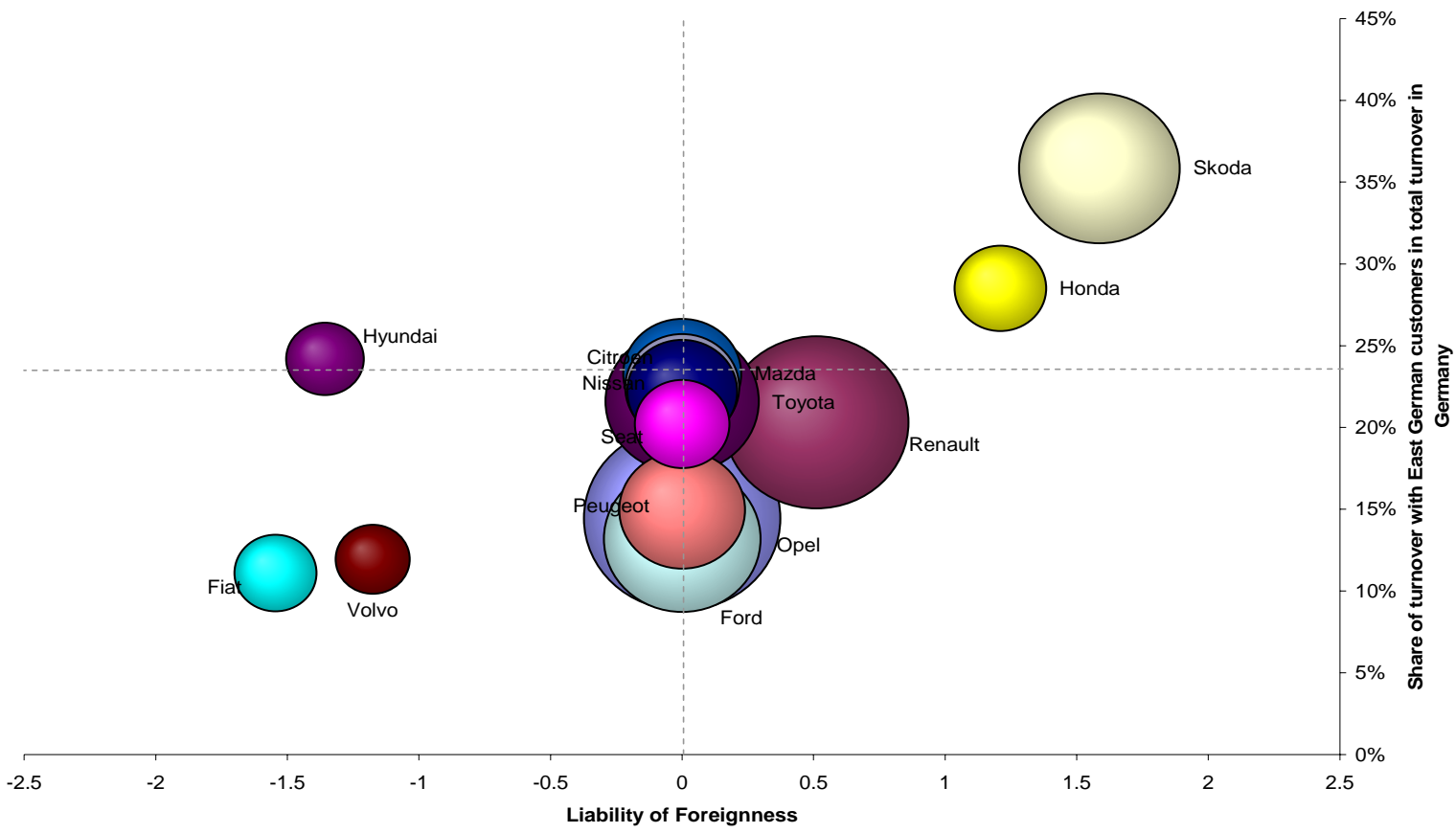

Figure 6.2: Importance-Liability-Matrix for West German customers

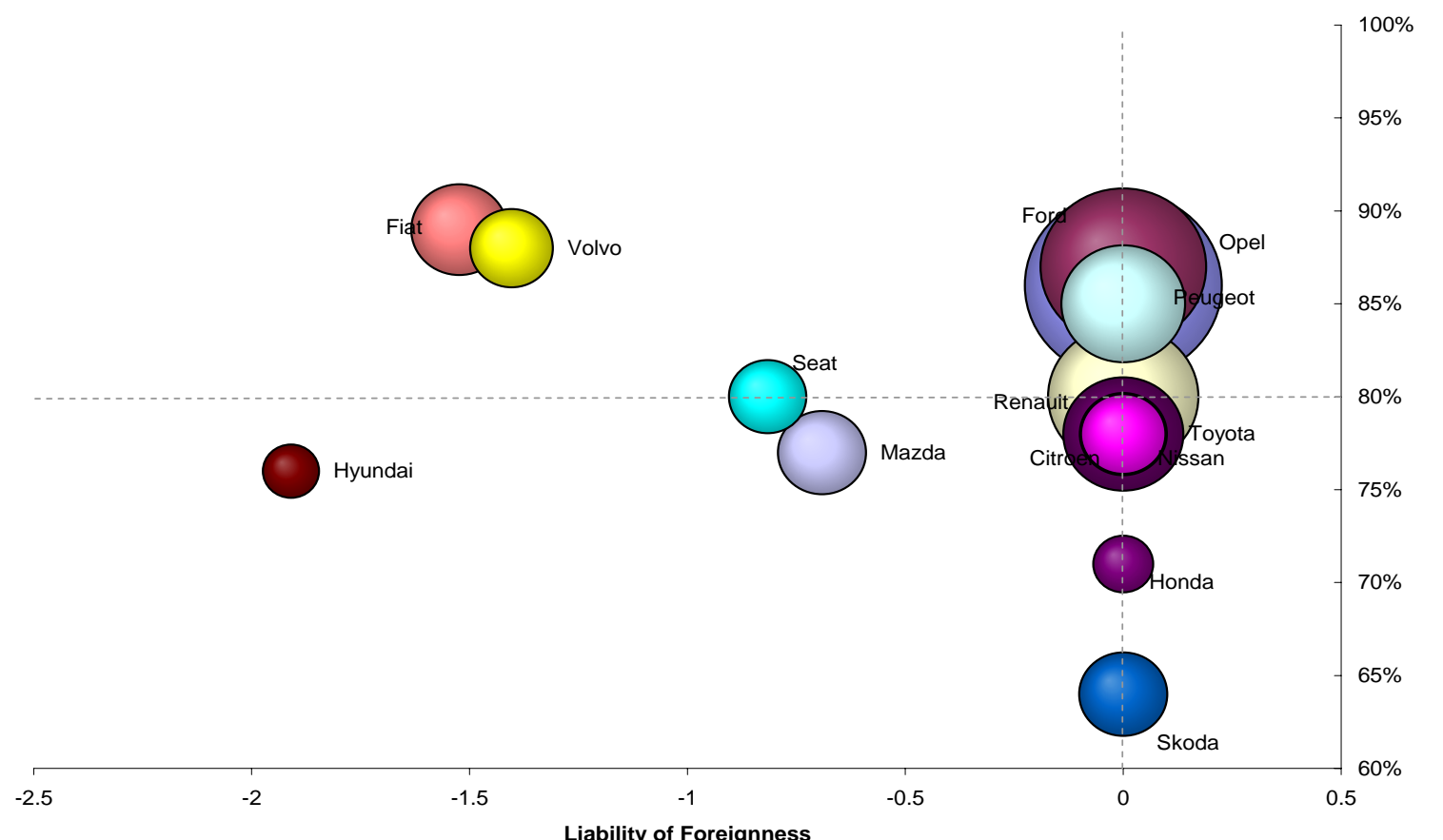

Note: The degree of liability of foreignness is the estimated, relative turnover disadvantage from chapter 5 , Table 5.2. Insignificant coefficients are set to zero (neutral). Bubble size represents total customer group turnover.

The matrix presented above allows interesting strategy derivations. First of all, Skoda and Honda hold excellent positions in Eastern Germany. The customer group is important to their 
overall German sales and their offerings fit so neatly into the Eastern German market context that they can even outperform traditional German competitors. They should focus on transferring best practices from East to West Germany (e.g., financing plans) and actively identify and engage regional markets in West Germany that resemble their successful East German environment. There is room for Renault to trade-in responsiveness for the Eastern German market in favor of more standardized offerings to optimize results: Their degree of liability of foreignness outperforms domestic competitors and the dangers from alienating an important customer group are limited. The opposite rationale is true for Hyundai. It earns roughly one out of four sales euros in Eastern Germany but its liability of foreignness there remains high. Hence, it cannot afford to be weak in this important market aspect and has to increase local responsiveness as a trade-off for global standardization. A good starting point could be to benchmark its complete offerings in Eastern Germany (product, brand, sales and service infrastructure) against the ones from better adapted competitors (Honda, Skoda, Renault).

Fiat and Volvo on the other side of the scale are adequately positioned in East Germany. While they have a relatively high degree of liability of foreignness in Eastern Germany, this market is also not vital to them in terms of turnover. Fiat and Volvo are severely challenged by liabilities of foreignness in their highly important West German market. Hence, we depart from our general assessment that East Germany is the better platform to overcome liabilities of foreignness. For Fiat and Volvo the problems are more deeply rooted and they should deploy offensive strategies in Western Germany or accept a secondary status.

In conclusion, this study was designed to assess the current degree of liability of foreignness from a market perspective and derive adequate strategic responses. We applied this conceptual framework to the large, established car market in Germany. Our results are twofold: Foreign competitors are not discriminated by German customers in general and a clever management can overcome liabilities of foreignness. We highlighted strategic challenges and opportunities where these leveraging effects could be achieved most effectively and efficiently. We find these strategic leverage points in disruptive changes of a society (such as caused by Germany's reunification) that invalidate the established social network and open up chances for newcomers from abroad to develop local embeddedness at equal rates as domestic competitors. On the German automotive market such opportunities arise primarily in East Germany while the socio-cultural effects of liabilities of foreignness appear more deeply rooted in the Western part. Besides, we identify a broader rational for all car producers to engage early and decisively in untapped, promising foreign markets (such as China) to prevent liabilities of foreignness and learn at equal rates as domestic competitors.

A more dynamic perspective across longer time spans would certainly help to understand and cope with these liabilities of foreignness. This was beyond the scope of this paper, however may be subject for future research. Additionally, a comparison across countries could lead to very interesting insights. Finally, we focused our attention on foreign companies in the German car market and how they compete with domestic rivals. One might very easily turn tables and interpret our results as a call to arms for the German producers in East Germany because ‘there’s no place like home.' 
Table 7.1: Descriptive statistics, standard errors in parenthesis

\begin{tabular}{|c|c|c|c|c|}
\hline Definitions & Variable & $\begin{array}{l}\text { Complete } \\
\text { sample }\end{array}$ & $\begin{array}{c}\text { German } \\
\text { manufacturers }\end{array}$ & $\begin{array}{c}\text { Foreign } \\
\text { manufacturers }\end{array}$ \\
\hline Turnover in Germany (mn €) & turnover & $\begin{array}{c}48.7 \\
(101.0)\end{array}$ & $\begin{array}{c}79.5 \\
(149.0)\end{array}$ & $\begin{array}{c}31.9 \\
(54.5)\end{array}$ \\
\hline $\begin{array}{r}\text { Turnover by customers located in East } \\
\text { Germany (mn } € \text { ) }\end{array}$ & toeast & $\begin{array}{c}6.0 \\
(13.0) \\
\end{array}$ & $\begin{array}{c}9.0 \\
(17.1)\end{array}$ & $\begin{array}{c}5.9 \\
(9.9)\end{array}$ \\
\hline Share of German sales on global turnover & gturn & $\begin{array}{c}6.44 \\
(4.68)\end{array}$ & $\begin{array}{l}11.15 \\
(3.93)\end{array}$ & $\begin{array}{c}3.87 \\
(2.59)\end{array}$ \\
\hline Media expenditures & media & $\begin{array}{c}36,197 \\
(17,850)\end{array}$ & $\begin{array}{c}39,701 \\
(15,925)\end{array}$ & $\begin{array}{c}34,292 \\
(18,547)\end{array}$ \\
\hline Share of R\&D investments on turnover & rndonturn & $\begin{array}{c}4.27 \\
(0.80)\end{array}$ & $\begin{array}{c}4.74 \\
(0.70)\end{array}$ & $\begin{array}{c}4.01 \\
(0.74)\end{array}$ \\
\hline $\begin{array}{r}\text { Number of month since market } \\
\text { introduction }\end{array}$ & mtime & $\begin{array}{c}23.32 \\
(11.70)\end{array}$ & $\begin{array}{c}23.35 \\
(11.56)\end{array}$ & $\begin{array}{c}23.31 \\
(11.78)\end{array}$ \\
\hline Kilowatts of engine power & kw3 & $\begin{array}{l}103.10 \\
(45.18)\end{array}$ & $\begin{array}{l}125.16 \\
(56.11)\end{array}$ & $\begin{array}{l}91.10 \\
(32.14)\end{array}$ \\
\hline Kilowatts of engine power in logs & $\operatorname{lnkw}$ & $\begin{array}{c}4.55 \\
(0.41)\end{array}$ & $\begin{array}{c}4.73 \\
(0.45)\end{array}$ & $\begin{array}{l}4.45 \\
(0.34)\end{array}$ \\
\hline Squared kilowatts of engine power in logs & sqlnkw & $\begin{array}{l}20.88 \\
(3.73)\end{array}$ & $\begin{array}{l}22.60 \\
(4.20)\end{array}$ & $\begin{array}{l}19.95 \\
(3.06)\end{array}$ \\
\hline $\begin{array}{l}\text { Weighted average of environmental } \\
\text { friendliness ranking per company }\end{array}$ & env & $\begin{array}{l}61.97 \\
(6.48)\end{array}$ & $\begin{array}{l}63.89 \\
(2.76)\end{array}$ & $\begin{array}{l}60.93 \\
(7.60)\end{array}$ \\
\hline Car model drives on diesel fuel (Dummy) & diesel & $\begin{array}{c}0.32 \\
(0.47)\end{array}$ & $\begin{array}{c}0.33 \\
(0.47)\end{array}$ & $\begin{array}{c}0.32 \\
(0.47)\end{array}$ \\
\hline $\begin{array}{r}\text { Normalized value loss in first year per } \\
\text { company }\end{array}$ & tloss & $\begin{array}{l}10.73 \\
(4.07)\end{array}$ & $\begin{array}{c}9.10 \\
(3.52)\end{array}$ & $\begin{array}{l}11.62 \\
(4.08)\end{array}$ \\
\hline Number of airbags & airbag & $\begin{array}{c}4.99 \\
(1.56)\end{array}$ & $\begin{array}{c}5.16 \\
(1.52)\end{array}$ & $\begin{array}{c}4.90 \\
(1.58)\end{array}$ \\
\hline $\begin{array}{r}\text { Car model has luxurious (e.g. wood) } \\
\text { interior decoration (Dummy) }\end{array}$ & interior & $\begin{array}{c}0.49 \\
(0.50)\end{array}$ & $\begin{array}{c}0.65 \\
(0.48)\end{array}$ & $\begin{array}{c}0.40 \\
(0.49)\end{array}$ \\
\hline $\begin{array}{r}\text { Car model has a navigation system } \\
\text { (Dummy) }\end{array}$ & navi & $\begin{array}{c}0.04 \\
(0.21)\end{array}$ & $\begin{array}{c}0.02 \\
(0.15)\end{array}$ & $\begin{array}{c}0.06 \\
(0.23)\end{array}$ \\
\hline Car is a convertible (Dummy) & cario & $\begin{array}{c}0.06 \\
(0.23)\end{array}$ & $\begin{array}{c}0.10 \\
(0.30)\end{array}$ & $\begin{array}{c}0.04 \\
(0.19)\end{array}$ \\
\hline Car is a station wagon (Dummy) & swagon & $\begin{array}{c}0.16 \\
(0.37) \\
\end{array}$ & $\begin{array}{c}0.20 \\
(0.40)\end{array}$ & $\begin{array}{c}0.14 \\
(0.35) \\
\end{array}$ \\
\hline Number of observations & & 1,383 & 487 & 896 \\
\hline
\end{tabular}




\section{$8 \quad$ References}

ACEA (2003), New Motor Vehicle Registrations, ACEA, http://www.acea.be/ASB/Download.nsf/Category1Language3Files/5406FA8968BAF9 F7C1256ED6004626FD/\$File/NewReg-2003-byCountry(New\%20Members).xls.

ACEA (2005), Motor Vehicles in Use (Car Parc), ACEA, http://www.acea.be/ASB/Download.nsf/Category1Language3Files/CA99B8E491FD3 FC7C1256F10004018EC/\$File/Car_Parc_1995-2002.pdf.

ADAC-AutomarxX (2003), Adac-Automarxx, ADAC

B\&D Forecast GmbH, http://www.bd-forecast.de/ENG/ADAC-AutoMarxX-Dezember-2003Presse.pdf.

ADAC (2004a), Adac-Pannenstatistik, ADAC, http://www.adac.de/Auto_Motorrad/pannen_und_maengel/pannenstatistik_2004/defau lt.asp?ComponentID=113337\&SourcePageID=9989\%230.

ADAC (2004b), Ecotest, ADAC, http://www.adac.de/images/22930_tcm8-117022.pdf.

Autobild (2005), Unter Zwillingen, Autobild, http://www.autobild.de/test/neuwagen/artikel.php?artikel_id=8976.

Automobil-Produktion (2005a), General Motors Zukunft 'Made in Ruesselsheim', AutomobilProduktion (Juli 2005), 8.

Automobil-Produktion (2005b), Heißer Tanz Um Kleine Autos, Automobil-Produktion (April 2005), 18-22.

Automobil-Produktion (2005c), Kooperationen Müssen Exklusiv Sein, Automobil-Produktion (April 2005), 24-25.

Automobil-Produktion (2005d), Teure Sackgassen Vermeiden, Automobil-Production (Mai 2005), 62-63.

Bartlett, C. and S. Goshal (1989), Managing across Borders: The Transnational Solution, Cambridge.

Bartlett, C.A. and S. Goshal (1987), Managing across Borders: New Organizational Responses, Sloan Management Review 29 (1), 43-54.

Bergfeld, M.-M. and M. Stahl (2005), The Role of Foreign Subsidiaries in the Innovation Process of German High-Tech Corporations: A Support to Building Global Innovation Networks Proceedings of R\&D Management Conference 2005, Pisa. 
Berkovec, J. and J. Rust (1985), A Nested Logit Model of Automobile Holdings for One Vehicle Households, Transportation Research Part B: Methodological 19 (4), 275285.

Berndt, E.R. (1991), The Practice of Econometrics: Classic and Contemporary, Reading.

Bilkey, W.J. and E. Nes (1982), Country-of-Origins Effects on Product Evaluation, Journal of International Business Studies 13 (1), 89-99.

Brownstone, D., D.S. Bunch and K. Train (2000), Joint Mixed Logit Models of Stated and Revealed Preferences for Alternative Fuel Vehicles, Transport Research Part B: Methodological 34 (5), 315-338.

Bunch, D.S., M. Bradley, T.F. Golob and R. Kitmura (1993), Demand for Clean-Fuel Vehicles in California - a Discrete Choice Stated Preference Pilot Project, Transportation Research Part A: Policy and Practice 27 (3), 237-253.

Cadillac (2005), Breakthrough Cadillac 2005 Cts, Cadillac, http://www.cadillac.com/cadillacjsp/models/feature.jsp?model=cts/05Cadillac_CTS.p df.

Caspary, S., K. Matoba and D. Schiereck (2003), Mergers and Acquisitions in Der Japanischen Automobilindustrie, Wittener Diskussionspapiere 123.

Caves, R.E. (1971), International Corporations: The Industrial Economics of Foreign Investment, Economica 38 (149), 1-27.

Chao, P. and P.B. Gupta (1995), Information Search and Efficiency of Consumer Choices of New Cars: Country-of-Origin Effects, International Marketing Review 12 (6), 47-59.

Chen, M.J. (1996), Competitor Analysis and Interfirm Rivalry: Toward a Theoretical Integration., Academy of Management Review 21 (1), 100-134.

Chueh, T.-Y. and D.T. Kao (2004), The Moderating Effects of Consumer Perception to the Impacts of Country-of-Design on Perceived Quality, Journal of American Academy of Business 4 (1/2), 70-74.

Cleff, T., O. Heneric and A. Spielkamp (2005a), Regulation and Industrial Policy, in: Heneric, O., G. Licht and W. Sofka (eds.), Europe's Automotive Industry on the Move: Competitiveness in a Changing World, Heidelberg, 157-190.

Cleff, T., G. Licht, A. Spielkamp and W. Urban (2005b), Innovation and Competitiveness, in: Heneric, O., G. Licht and W. Sofka (eds.), Europe's Automotive Industry on the Move: Competitiveness in a Changing World, Heidelberg, 103-156.

Court, A.T. (1939), Hedonic Price Indexes, General Motors Corporation, in: Court, A. T. (ed.) The Dynamics of Automobile Demand, New York, 99-117.

de Mooij, M. (2000), The Future Is Predictable for International Marketers, International Marketing Review 17 (2/3), 103-124. 
Devinney, T.M., D.F. Midgley and S. Venaik (2000), The Optimal Performance of the Global Firm: Formalizing and Extending the Integration-Responsiveness Framework, Organization Science: A Journal of the Institute of Management Sciences 11 (6), 674695.

DeYoung, R. and D. Nolle (1996), Foreign-Owned Banks in the United States: Earning Market Share or Buying It? Journal of Money, Credit, and Banking 28, 622-636.

Diamantopoulos, A., B.B. Schlegelmilch and J.P. Du Preez (1995), Lessons for Pan-European Marketing? The Role of Consumer Preferences in Fine-Tuning the Product-Market Fit, International Marketing Review 12 (2), 38-52.

Diehl, M. (2001), International Trade in Intermediate Inputs: The Case of the Automobile Industry, Kiel Working Paper No. 1027, Kiel.

Doz, Y.L. (1980), Strategic Management in Multinational Companies, Sloan Management Review 21 (2), 27-46.

Doz, Y.L. and C.K. Prahalad (1984), Patterns of Strategic Control within Multinational Corporations, Journal of International Business Studies 15 (2), 55-72.

Doz, Y.L., J. Santos and P. Williamson (2001), From Global to Metanational: How Companies Win in the Knowledge Economy, Boston.

Eden, L. and S.R. Miller (2004), Distance Matters: Liability of Foreignness, Institutional Distance and Ownership Strategy, Bush School Working Paper No. 404.

Eden, L. and M.A. Molot (2002), Insiders, Outsiders and Host Country Bargains, Journal of International Management 8 (4), 359-388.

Emanuel, I. (2002), The European Motor Vehicle Block Exemption: An Update, PricewaterhouseCoopers Global Automotive Financial Review, http://www.pwcglobal.com/Extweb/industry.nsf/docid/3690EA483AFBA6FA852568 7E00590EA.

European Commission (2004), Eu Industrial R\&D Investment Scoreboard, Brussels.

Goldberg, P.K. and F. Verboven (2001), The Evolution of Price Dispersion in the European Car Market., Review of Economic Studies 68 (4), 811-849.

Goldberg, P.K. and F. Verboven (2004), Cross-Country Price Dispersion in the Euro Era: A Case Study of the European Car Market., Economic Policy 19 (40), 484-522.

Gomes, L. and K. Ramaswamy (1999), An Empirical Examination of the Form of the Relationship between Multinationality and Performance, Journal of International Business Studies 30 (1), 173-188.

Goshal, S. and C. Bartlett (1990), The Multinational Corporation as an Interorganizational Network, Academy of Management Review 15, 603-625. 
Govindarajan, V. and A.K. Gupta (2001), The Quest for Global Dominance: Transforming Global Presence into Global Competitive Advantage, 1, San Francisco.

Granovetter, M. (1985), Economic Action and Social Structure: The Problem of Embeddedness, American Journal of Sociology 91 (3), 481-510.

Grein, A.F., C.S. Craig and H. Takada (2001), Integration and Responsiveness: Marketing Strategies of Japanese and European Automobile Manufacturers, Journal of International Marketing 9 (2), 19-50.

Griffiths, W.E., C. Hill and G.G. Judge (1992), Learning and Pacticing Econometrics, New York.

Griliches, Z. (1961), Hedonic Price Indexes for Automobiles: An Econometric Analysis of Quality Change. The Price Statistics of the Federal Government, NBER General Series 73 (3), 173-196.

Gupta, A.K. and E.D. Westney (2003), Introduction, in: Gupta, A. K. and E. D. Westney (eds.), Smart Globalization: Designing Global Strategies, Creating Global Networks, San Francisco, 1-12.

Hakim, D. (2005), G.M. And Ford Stuck in Neutral as Buyers Look Beyond Detroit, The New York Times, http://www.nytimes.com/2005/04/15/automobiles/15auto.html?pagewanted=all\&posit ion=\#.

Han, M.C. and V. Terpstra (1988), Country-of-Origin Effects for Uni-National and BiNational Products, Journal of International Business Studies 19 (2), 235-255.

Hasan, I. and W. Hunter (1996), Efficiency of Japanese Multinational Banks in the United States, in: Chen, A. H. (ed.) Research in Finance, Greenwich and London, 157-173.

Heinlein, R. (1961), Stranger in a Strange Land, New York.

Heneric, O., G. Licht and W. Urban (2005), The European Automotive Industry in a Global Context, in: Heneric, O., G. Licht and W. Sofka (eds.), Europe's Automotive Industry on the Move: Competitiveness in a Changing World, Heidelberg, 5-44.

Hennart, J.-F. (1982), A Theory of Multinational Enterprise, Michigan.

Hitt, M.A., R.E. Hoskisson and R.D. Ireland (1994), A Mid-Range Theory of the Interactive Effects of International and Product Diversification on Innovation and Performance, Journal of Management 20 (2), 297-327.

Hsieh, M.-H. (2004), An Investigation of Country-of-Origin Effect Using Correspondence Analysis: A Cross-National Context., International Journal of Market Research 46 (3), 267-295.

Hymer, S.H. (1976), The International Operations of National Firms: A Study of Direct Investment, Cambridge. 
Jensen, R. and G. Szulanski (2004), Stickiness and the Adaption of Organizational Practices in Cross-Border Knowledge Transfers, Journal of International Business Studies 35 (6), 508-523.

Jürgens, U. (2003), Characteristics of the European Automotive System: Is There a Distinctive European Approach? WZB discussion paper No. 301, Berlin.

Kaminski, B. and F. Ng (2001), Trade and Production Fragmentation: Central European Economies in European Union Networks of Production and Marketing, World Bank Policy Research Working Paper No. 2611.

Khurana, A. and S.R. Rosenthal (1997), Integrating the Fuzzy Front End of New Product Development, Sloan Management Review 38 (2), 103-120.

Kleinschmidt, E.J. and R.G. Cooper (1988), The Performance Impact of an International Orientation of Product Innovation, European Journal of Marketing 22 (10), 56-72.

Koolen, S., Y. Tminiau and C. Faber (2005), Monti and Market Dynamics: The Strategy of a National Car Importer, European Management Journal 23 (4), 413-425.

Lessard, D.R. (2003), Frameworks for Global Strategic Analysis, Journal of Strategic Management Education 1 (1), 19-37.

Levitt, T. (1983), The Globalization of Markets, Harvard Business Review 67, 152-61.

Licht, G., W. Sofka and W. Urban (2005), Competitiveness: A Market Perspective, in: Heneric, O., G. Licht and W. Sofka (eds.), Europe's Automotive Industry on the Move: Competitiveness in a Changing World, Heidelberg, 45-102.

Lord, M.D. and A.L. Ranft (2000), Organizational Learning About New International Markets: Exploring the Internal Transfer of Local Market Knowledge, Journal of International Business Studies 31 (4), 573-589.

Luo, Y., O. Shenkar and M.-K. Nyaw (2002), Mitigating Liabilities of Foreignness: Defensive Versus Offensive Approaches, Journal of International Management 8 (3), 283-301.

Mezias, J.M. (2002a), How to Identify Liabilities of Foreignness and Assess Their Effects on Multinational Corporations., Journal of International Management 8 (3), 265-283.

Mezias, J.M. (2002b), Identifying Liabilities of Foreignness and Strategies to Minimize Their Effects: The Case of Labor Lawsuit Judgement in the United States, Strategic Management Journal 23, 229-244.

Miller, S.R. and A. Parkhe (2002), Is There a Liability of Foreignness in Global Banking? An Empirical Test of Banks’ X-Efficiency, Strategic Management Journal 31 (1), 323337.

Miller, S.R. and M. Richards (2002), Liability of Foreignness and Membership in a Regional Economic Group: Analysis of the European Union, Journal of International Management 8 (3), 323-337. 
Nagashima, A. (1970), A Comparison of Japanese and U.S. Attitudes toward Foreign Products, Journal of Marketing 34, 68-74.

Nunnenkamp, P. (2000), Globalisierung Der Automobilindustrie: Neue Standorte Auf Dem Vormarsch, Traditionelle Anbieter Unter Druck? Kieler Arbeitspapier 1002.

Ohmae, K. (1990), The Borderless World: Power and Strategy in the Interlinked Economy, New York.

OICA (2004), Oica Statistics World Motor Vehicle Production, OICA, http://www.oica.net/htdocs/statistics/tableaux2004/worldprod_cars2004-3.pdf.

Pareja, S.G. (2001), Pricing to Market in European Automobile Exports to Oecd Countries: A Panel Data Approach, Applied Economics 33 (14), 1845-1856.

Petersen, B. and T. Pedersen (2002), Coping with Liability of Foreignness: Different Learning Engagements of Entrant Firms, Journal of International Management 8 (3), 339-350.

Prahalad, C.K. and Y.L. Doz (1987), The Mulinational Mission: Balancing Local Demands and Global Vision, 1, New York.

Reich, R. (1990), Who Is Us? Harvard Business Review 68 (1), 53-64.

Reierson, C.C. (1966), Are Foreign Products Seen as National Stereotypes, Journal of Retailing 42, 33-40.

Rosen, S. (1974), Hedonic Prices and Implicit Markets: Product Differentiation in Pure Competition, The Journal of Political Economy 82 (1), 34-55.

Roth, K. and A.J. Morrison (1990), An Empirical Analysis of the Integration-Responsiveness Framework in Global Industries, Journal of International Business Studies 21 (4), 541-564.

Rugman, A.M. and A. Verbeke (1998), Multinational Enterprises and Public Policy, Journal of International Business Studies 29 (1), 115-136.

Scholler, R.D. (1965), Product Bias in the Central American Common Market, Journal of Marketing Research 2, 394-407.

Sofka, W. and T. Schmidt (2004), I Like the Way You Move: An Empirical Investigation into the Mechanisms Behind First Mover and Follower Strategies, ZEW Discussion Paper No. 04-87, Mannheim.

Train, K. and G. Sonnier (2002), Mixed Logit with Bounded Distribution of Correlated Pathworks, University of California Berkeley Working Paper, http://elsa.berkeley.edu/wp/train1202b.pdf.

UNCTAD (2003), World Investment Report 2003, New York, Geneva.

VDA (2003), International Auto Statistics, Frankfurt. 
VDA (2004), Auto Jahresbericht, Frankfurt.

Verboven, F. (1998), Testing for 'Monopoly' Market Power When Products Are Differentiated in Quality., Manchester School 70 (1), 115-134.

Verboven, F. (2002), Quality-Based Price Discrimination and Tax Incidence: Evidence from Gasoline and Diesel Cars., RAND Journal of Economics 33 (2), 275-298.

Wooldridge, J.M. (2002), Econometric Analysis of Cross Section and Panel Data, Cambridge.

Zaheer, S. (1995), Overcoming the Liability of Foreignness., Academy of Management Journal 38 (2), 341-364.

Zaheer, S. (2002), The Liability of Foreignness, Redux: A Commentary, Journal of International Management 8 (3), 351-358.

Zaheer, S. and E. Mosakowski (1997), The Dynamics of the Liability of Foreignness: A Global Study of Survival in Financial Services, Strategic Management Journal 18 (6), 439-464.

Zaheer, S. and A. Zaheer (1997), Country Effects on Information Seeking in Global Electronic Networks, Journal of International Business Studies 28 (1), 77-100.

Zellner, A. (1962), An Efficient Method of Estimating Seemingly Unrelated Regressions and Tests of Aggregation Bias, Journal of the American Statistical Association 57 (298), 348-368. 